\begin{tabular}{lr}
\hline 講 & 座 \\
R E V I E W \\
\hline
\end{tabular}

織維強化複合材料の強度理論*

林

毅**

\title{
The Fundamental Theory of Strength of Fiber-Reinforced Composite Materials
}

Tsuyoshi Hayashi

\section{1. 綞維強化複合材料の発展と綝維強化の機構}

在来の材料裺合法の思想は 1940 年以来この 30 年間 に画期的な発展をとげた.これを 3 期
I. 1940〜1960 FRP の発展
II. 1955 1965 FW 法の発展
III. 1960 1970 FRM の発展
WRM, FRR の開発

に分けるととができる.

1940 年加ら 1960 年までの第 I 期には, 繊維強化プ ラスチックス (FRP: Fiber Reinforced Plastics) の 工業用材料としての発達と定着があった. 代表的なす のにグラスクロス・エポキシ樹脂皘層板より成る航空 機構造部品や線巻き構造のロケット・チャンバーがあ り，てれらはいずれも比強度，比剛性がすぐれ，軽量 化化役立ってきているてとは周知のとてるである ${ }^{1) ~ 8) ~}$

今日グラス緎維とポリエステル臌脂またはエポキシ 樹脂との組み合わせによって代表される FRP が織維 分散強化材料として発展し，弾性率強度とも1945 年 初期のころよりは格段の進歩をとげた。初期のころ FRP は主要構造部材以外の 2 次構造材としてしか使

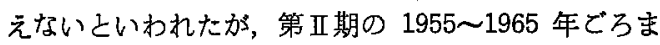
での線巻き (Filament-Winding) 技術の確立 ${ }^{11}$ と, 線 巻きロケット・チャンバーの実現は，乙の材料が単に 2 次棈造物から，主要構造用として実用性を獲得した あのとして画期的な時期であった，人間衛星船の大気 再入時における熱吸収材としてあやはりグラスクロ ス・エポキシまたはフェノール積層材が融燃材料 (ablation material) として最適であることが寒証された

* 本稿は 1968 年 4 月 5 日，日本航空学会年会における “Composite Materials” シンポジゥムにおいて複合材 料の強度理論と題し発表した内容にその後の著者の研 究と文献をさらに引用加筆したものである. 昭和 43 年 12 月 19 日原禞受理

** 東京大学工学部航空学科
ととは興味深い．この第II期は正に，瀻維強化複合材 料 (FRCM : Fiber Reinforced Composite Material) が主要構造材料としての有用性を評価された時代とし てその意義は誠に大きい。

織維分散強化法のこのような発展は，それまで金属 材料の強化法として専ら考えられていた粒子分散強化 法の思想を変えすににはおかなかった。つまり強化用に 入れる粒子の径は 0.1〜0.01 ミクロンという微細であ るととが必要で. それによってマトリクスを 10〜25 倍強化させ得るのであるが，そ机より大きい径の粒子 では強化の効果が低いのである．そもそもこの粒子分 散強化法の原理は粒子によって内部の転位（dislocation）の移動が拘束され塑性変形が起こりにくいため 亿強度が上がるとされている．ところが FRP や FW では径 5〜10 ミクロンのグラス・ファイバーを使い, たとえば断面皘 $1 \mathrm{~cm}^{2}$ の棒内には $1 \sim 2$ 万本す束极て 入れることになるので. このような大きい径のあのに よって十分大きい強化率が得られるという事実は上記 の原理と相反するととであった。粒子分散強化原理と は全く異質の強化の原理がそこにあったのであった。 つまり, 緎維強化法ではマトリクス(強化される地材) は, 絏維を適当にマトリクス内に無接触に位置づけ し, 絨維から絨維へ上剪断応力の形で力を伝達する媒 体 (パインダー; 結合材) として䣦くのである.てれ が粒子分散法と違った繊維強化原理なのである.

第而期の 1960１970 年はこのような思想的発展に 支えられて新しく織維強化金属 (FRM：Fiber Reinforced Metal) が試作され発展してきた。針状単結晶 (Whiskers) によるウィスカー強化金属 (セラミック・ ウィスカース；たとえばアルミナ $\mathrm{Al}_{2} \mathrm{O}_{3}$ ，シリカ $\mathrm{SiO}_{2}$ などによって強化したアルミニウムなど）とか，ボロ ン瀻維やカーボン緎維によって強化したチタニウムや アルミニウムなどのあつポテンシアルがクローズ・ア ップされた. 宇宙工学・科学におりる, より軽量で高 
い耐熱性をむつ材料への強い要請は, 高温強度の大き いウィスカースの開発とそれによる耐熱複合金属材料 の研究を促さずにはおかなかった. ウィスカースにつ いては 1952 年以来その成長法之特性の研究が続けら れ9，1961 年に最初のウィスカー CM が作られた. 1967 年米国 GE の SUTTON は長さ $70 \mathrm{~mm}$ のアルミ ナ・ウィスカース $\left(\mathrm{Al}_{2} \mathrm{O}_{3}\right)$ の成長に成功した. 以上の ような高温でも弾性率と強度の大きいセラミック・ウ イスカーやカーボン絨維の開発はこの第而期発展の端 粕となった. 次いで 1959 年 JECH, WEBER, SCHWOPE

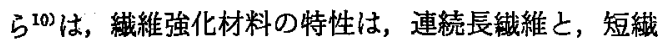
維のいずれを使ったものであ本質的に同じであること を実験的に発見し，てれは1960年 MCDANELS, JECH，

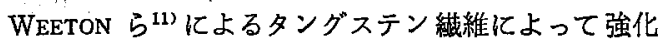
した銅についての実験で確認された。との発見は，長 いウィスカースの製法が困難な現在でも，たとえ短か くても長いもの之同様の強化が達成できるととを示し たものとして意義が大きい.

さらに MCDANELS ら ${ }^{12}$ は W-Cu 複合材料の実験 によって複合則 (law of mixture) の成立を確証した. それまでFRP では，FW を除いては強化の解析理諭 に欠けていたのであった. FRCM の材料力学的問題 としては (1) 䄉維強化の理論, (2) FRCM の力学的 特性の解析理諭 (弹性, 強度, 疲れ, クリープ, 破壞 など）また FRCM 材で作った構造物の力学的問題と しては (3) FRCM 構造の応力解析理論 (直交異方性, 多方向異方性のあるものの)，(4) FRCM 構造の強度 理諭（座屈理諭など）のおのおのについて広く研究が 特に米国，英国，日本にてすすめられてきた．特に (2)については，織維でとの振舞を解析するマイクロ メカニックス (micromechamics) が最近ようやく盛ん になりつつある. 今後, 分散䄉維の挙動を詳しくとら える理論的研究のコンピューターによる発展が期待さ れる. 問題(3)，(4)については従来より確立されてき た直交異方性理論が役立つと同時に，また一般な力向 性をすつ構造についてもその確立が望まれている．顕 微光弾性解析法は，マイクロメカニックスの有力な力 法を提供する。このような解析理論はさらに，紼維強 化の根本的なメカニズム，その破壊とクラック伝播の 機構の解明泊り, 界面問題 (接着破壊と凝集破壊, 化学的接着之破壊など）粘弾塑性的振舞などの研究が 行なわれるようになった。

一方において従来のゴムをコードで強化したタイヤ 材料を含む，いわゆる繊維強化エラストマー（FRRFiber Reinforced Rubber) が，今日の新しい視野か ら見直され新しい発展を促されつつある。

FRCM はこの上うに柔加い材料から固い材料まで
ヤング率では $E=\left(1 \times 10^{-2} \sim 1 \times 10^{4}\right) \mathrm{kg} / \mathrm{mm}^{2}$, 温度域 は $T=(-100 \sim 1,500)^{\circ} \mathrm{C}$ に亘って，目的に応じた適

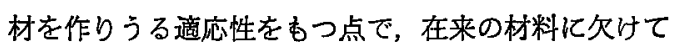
いたメリットによる合理性, 高性能化, 軽量化を約束 しているといえよう.

ての小論では頁数の制約から以下特に FRCM の強 度理諭の最屯基本的な重要な一方向強化材料の強度理 諭を主として考察するととにする。

\section{2. 縕維強化の理論}

一方向に平行に瀻維を入れた“一方向強化材” (unidirectionally reinforced material) について考察する. 線巻き構造，皘層構造などの弾性，強度の推定の基礎 になる最も簡単で重要な複合材料の基本形である。

\section{1 連続繰維による一方向強化材 この材料から} 紻維に平行に切り出した板（第 1 図(a)) が, 䋐維方向 の引張力 $P$ をうりるとき，㵶維とマトリクスが十分よ く結合している場合には，織維もマトリクスも相互に すべることなく，同じ伸びひずみをうけるとしてょ い. との系を(b) のような纎維 $f$ とマトリクス $m$ の 2 基材から成る系にモデル化してれが同じ伸びひずみ を生ずるとし, 各要素の弾性係数を $E_{f}, E_{m}$; 断面皘 $A_{f}, A_{m}$; 引張応力 $\sigma_{f}, \sigma_{m}$ をもつ之すると, 力のつり あいから

$$
P=\sigma_{c} A=\sigma_{f} A_{f}+\sigma_{m} A_{m}
$$

こてで $\sigma_{c}$ はこの複合材料のうける平均引張応力, $A=$ $A_{f}+A_{m}=$ 全断面皘, 㵶維とマトリクスの体積含有率 $V_{f}, V_{m}$ は，乙の板の長さをしとして

$$
V_{f}=A_{f} l /(A l)=A_{f} / A, V_{m}=A_{m} / A=1-V_{f}
$$

よって上式とから

$$
\sigma_{c}=\sigma_{f} V_{f}+\sigma_{m} V_{m}=\sigma_{f} V_{f}+\sigma_{m}\left(1-V_{f}\right)
$$

瀻維とマトリクスの応力・ひずみ曲線が第 2 図の $f, m$ のように与えられるときは，弾性域【における 複合材としての平均弾性係数 $E_{c}$ は $\varepsilon=\sigma_{c} / E_{c}=\sigma_{f} / E_{f}$ $=\sigma_{m} / E_{m}$ を(1)に入れ

$$
E_{c}=E_{f} V_{s}+E_{m}\left(1-V_{s}\right)
$$

(1), (2) を応力, 弾性係数の複合則 (law of mixture）という. 領域II では $m$ は塑性を示すので $\sigma_{f}=$ $E_{f} \varepsilon, \sigma_{m}=\sigma_{m y}$ (降伏点) であり,

(a)

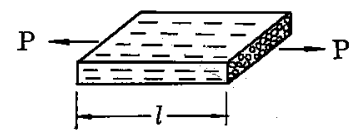

(b)

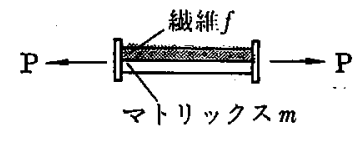

符 1 図一方向強化複合材（a)と，2基材モデル(b) 


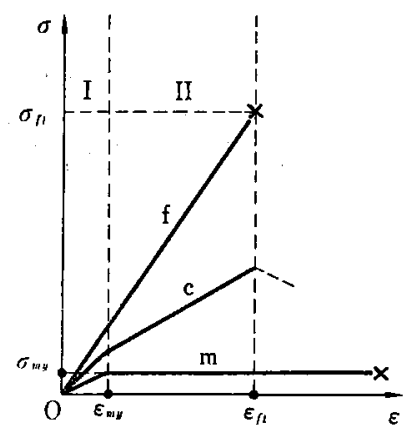

第 2 図 勘材 $(f, m)$ および複合材 (c) の 応力ーひずみ $(\sigma \sim \varepsilon)$ 明線

$\sigma_{c}=E_{f} V_{f} \varepsilon+\sigma_{m y}\left(1-V_{f}\right)$

$E_{c}=E_{s} V_{f}$

今，複合材の破壊が，各䋐維の同時破断によってお こるとすると, 複合材の引張強さは (3)から

$$
\sigma_{c}=\sigma_{s t} V_{f}+\sigma_{m v}\left(1-V_{f}\right)
$$

となる.ここで $\sigma_{f t}$ は複合材を作るときと同じ処理を 施した繊維の引張強さである。マトリックスが加工硬 化を示す場合には一般に，

$$
\sigma_{c}=\sigma_{f t} V_{f}+\sigma_{m}^{*}\left(1-V_{f}\right)
$$

と表わされる， $\sigma_{m}{ }^{*}$ は緎維破断ひずみ $\varepsilon_{f t}$ に対応する マトリックスの応力である. (5)，(6) を強度の複合 則という. 第 3 図の直楾 $A C$ は (6)による $\sigma_{c} \sim V_{f}$ の 直線関係を示す. 引張強さは䋞維含有率 $V_{f}$ を大きく するほど大きくなる。

一般に $\sigma_{m}^{*}$ はマトリックスの引張強さ $\sigma_{m t}$ とは一致 しない， $\sigma_{m t}$ と同じ強さ $\sigma_{c}$ を与えるような $V_{f}$ を最小 㵶維含有率といい

$$
V_{f \min }=\left(\sigma_{m t}-\sigma_{m} *\right) /\left(\sigma_{f t}-\sigma_{m}^{*}\right)
$$

である. との $\sigma_{m t}$ の点 $B$ に対応する $A C$ 上の点 $B^{\prime}$ を 等破壊点 (Break-even point) という. 㵶維含有率を これよりる大きくしないと，強化の効果がない.

$V_{f}$ は最大 1.0 であるが, 円形断面の㵶維の場合 $V_{f \max }=2 \pi /(4 V \overline{3})=92.2 \%$ となり，互に接触してし まう. 実験によると脆い纎維では $V_{s} \geqq 80 \%$ では圧縮 と曲げ強さは低下する．纎維が接触すると強さを失う ので, $V_{f}=80 \%$ は実用上の限界であろう. FW 材で

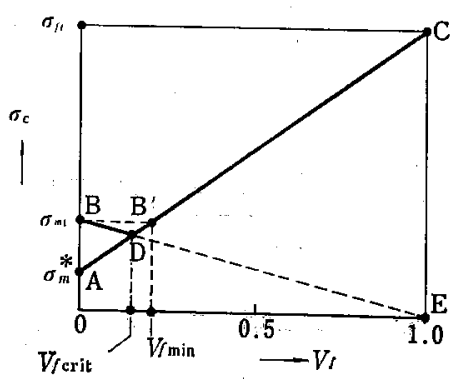

第3図連続瀻維による一方向強化材の引張强 さ $\sigma_{c}$ と絨維容積比 $V_{f}$ の間の複合則

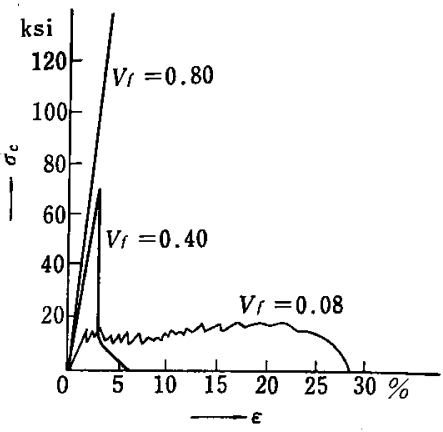

第 4 図 緉維体皘含有率 $V$ による応力ーひずみ 曲線の破壊形式の変化

は $V_{f}=65 \sim 70 \%$ が普通である.

第 4 図は $\mathrm{KELLX}{ }^{132}$ の W-Cu 複合材の $V_{f}$ を，0.08， $0.4,0.8$ Kटって実験した応力 $\sigma_{c} \sim$ ひずみ曲線を示 す. $V_{f}=0.08$ つまり㵶維含有率の小さい場合には, 引張りによって纎維には大きな応力がかかり，最す弱 い纎維がまず破断し，それが受けていた荷重は他の織 維に配分され，つぎに弱いすのが破断しつぎつぎと破 断がすすむ.このようにして jig-jag をもつ曲線にな る.との場合、マトリックスが荷重を受け取ることに なり，複合材の引張強さとして

$$
\sigma_{c}=\sigma_{m t}\left(1-V_{f}\right)
$$

を得る. (6)と ( 8 )を等置して得られる $V_{f}$ の值

$$
V_{f \text { crit }}=\left(\sigma_{m t}-\sigma_{m}^{*}\right) /\left(\sigma_{f t}+\sigma_{m t}-\sigma_{m}^{*}\right)
$$

は，第 3 図におりる $D$ 点の $V_{f}$ の值であり，てのよう な容積比をむつ複合材では，緎䧽の逐次破壊を生ず る.

MCDANELS ら ${ }^{11), 12) や K E L L Y ~}{ }^{13), 14)}$ は平行に整列 させたタングステン線（W）のまわりに銅を鋳込んで 作った W-Cu 複合材について，上述の複合則の成り 立つととを実験的に確めた，第 5 図(a)，(b) に見るよ うに，複合則のよく成り立つととがわかる(5),16).

第 6 図(a)，(b)はグラス・エポキシ複合材の例で $E_{f}$ $=7,400, \sigma_{f t}=200 \mathrm{~kg} / \mathrm{mm}^{2}$, ポアソン比 $\nu_{f}=0.22$, 比 重 $\gamma_{f}=2.60, V_{f}=0.70, E_{m}=350, \sigma_{m y}=\sigma_{m t}=8 \mathrm{~kg} /$ $\mathrm{mm}^{2}, \nu_{m}=0.35, \gamma_{m}=1.15, V_{m}=0.30$ としそれぞれ (a) 図 $f, m$ の応力一ひずみ特性をもつとして, 複合 材の特性 $c$ を求めている. 引張強さは： $\sigma_{\varepsilon}=8+192 V_{f}$, 比重は $\gamma_{c}=\gamma_{f} V_{f}+\gamma_{m}\left(1-V_{f}\right)=1.15+1.45 V_{f}$ となる 加ら, 比引張強さは $\sigma_{c} / \gamma_{c}=\left(8+192 V_{f}\right) /(1.15+1.45$ $\left.V_{f}\right)$ 上表わされとれを(b)に示してある.Vを大きく するほど比強度が大きくなる． $V_{f}=0.70$ のとき 65.6 $\mathrm{kg} / \mathrm{mm}^{2}$ である.

とれまでの議論では，䄉維はすべて連続で同し強さ をもち，引張り荷重にすへて平行であるという理想的 な複合材について考えた。しかし上記の複合則! (6) は,むしも䋘維強度のムラ（パラッキ）や）や維維方 

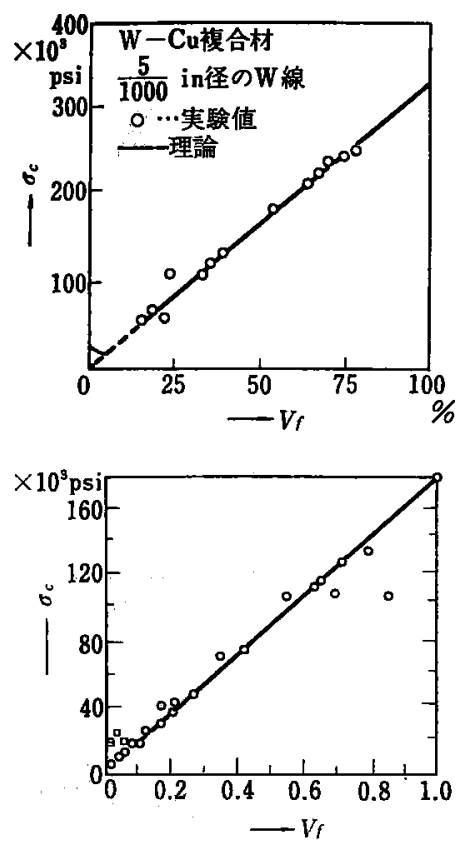

(b)

第 5 図 (a) McDanels ら [11] の W-Cu 複合材 の引張強さと $V_{f}$ との (b) KeLLY [13]によ るW脆性紻維 (径 $0.5 \mathrm{~mm}$ ) 之銅の複合材の室 温におりる引張強さ $\sigma_{\epsilon}$ と $V_{f}$ の関係 (1964)
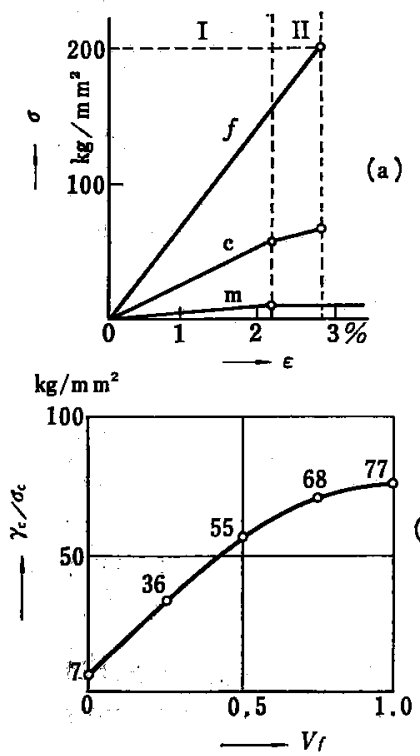

第 6 図 グラス綪維・エポキシ樹脂強化材の特性例

向の不整を考えに入れるなら式中の $\sigma_{f t}$ として

$$
\sigma_{s t}=\beta \bar{\sigma}_{f t}
$$

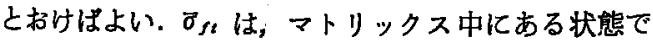
の䄉維の強さの平均值 (束強度 bundle strength) で, $\beta$ は計算と実際の (有効な) 瀻維応力の間の㲘隔を示 す係数である．このほか複合材料の強度に影響を及ぼ

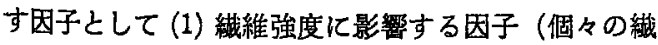

維の引張強さ $\sigma_{f t}$, 集団 (束) 強度 $\bar{\sigma}_{f t}$, 製造時の取り 扱いと工程の間の強度劣下，体積含有率 $V_{f}$ ，織維の 直径または長さと強度の関係, 強度と温度の関係, 破

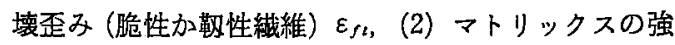
度に影響する因子(マトリックスの降伏強さ $\sigma_{m y}$, 引張 強さ $\sigma_{m t}$, 体積含有率 $V_{m}$, 荷重による変形に伴う加 工硬化の量 $\sigma_{m t}-\sigma_{m}{ }^{*}$, 強さ（特に䇂断強さ）対温度の 関係，(3) マトリックスからファイバーへの力の伝達 性に影響する因子（CM 構成要素の応力一歪み曲線之 弾性率比 $E_{f} / E_{m}, E_{f} / G_{m}$ ，マトリックス中に埋もれて いる状態でのファイバーの平均応力 $\vec{\sigma}_{f s,}$ 䄉維の体積 含有率 $V_{f}$, マトリックスの剪断強さ $\tau$ と剪断弾性率 $G_{m}$, 界面接着強さ $\tau_{b}$, 纎維限界長さ $l_{c}$, 纎維の長さ $l$ とアスペクト比 $l / d$, 㵶維の方位角 $\theta$, 複合材料の 破壊モードと，緎維破壊の統計的モード）の3つに分 類できる. これらの因子の検討はこてでは省略する.

2.2 不連続繊維による一方向強化材 つぎ同じ 長さの短織維を平行に入れた一方向強化材の板におい ては，各㵶維の作用はおのおのの間隔が余り狭くなけ ればそれをとりまくマトリックスとの相互作用がおの おの独立と見做されるので，それを第 7 図(a)のように 単純化ができよう.とのような 2 次元モデル化につい ては林の解析的研究 ${ }^{18)}$,20),21) があり, 光弾性的研究に

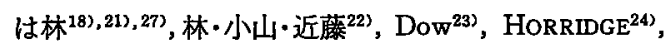
SChuster-SCAlA ${ }^{25)}$ ，河田 ${ }^{199}$ ，MUllin BERRY-GA$\mathrm{TTI}^{26)}$, 河田ら ${ }^{28)}$ ののがある.

著者は第 7 図（a）のような無限に広いマトリクス板 が中に含ませた䄉維の方向 $(x)$ に一様引張応力 $\sigma_{m}$ を うける場合の補強効果をしらへた ${ }^{18) 20)}$. 㵶維 $(F)$ の 長さ $l$, 断面積 $A_{f}$ で厚さはマトリクス板 $(M)$ と同 じで $t$ とする. $F$ は $M$ と同様に伸ばされようとし抵 抗する.今，界面では $F$ は $M$ と完全に接着してずれ は起とらないとする． $M$ に生ずる応力場は 2 次元平 面応力場と考えてよい.ささて $F$ の側面には $M$ 加ら第 7 圀 (b) のような分布剪断応力 $\tau$ をうけ， $M$ は $F$ か ら $d x$ 部分の両側面について合力 $\Delta P=2 \tau t d x$ の反 力をうける. $\triangle P$ の分布は $F$ 中点任関し左右対称であ る.（a）の応力分布は (b) と（c）の合成と見做すと之 ができる.ここで (c) は，中に䋳維をむたないマトリ クスだけの無限平板であって，織維のあった位置に， 緘維の代わりに反力 $\Delta P$ が分布して㗢くとしている.

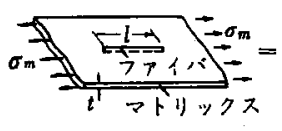

(a) 単織維コンポジット

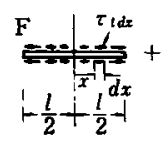

(b) 維離

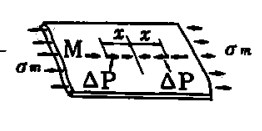

(c) マトリックス板
第7図 轿維とマトリクスの相互作用 
乙の分布力 $\triangle P$ 之, 元々かかっている一様引張応力 $\sigma_{m}$ とによって， $x$ 軸上の任意点 $(x)$ 飞生ずる $x$ 方向 の伸び歪み $\varepsilon(M)$ は

$$
M: \varepsilon(M)=\varepsilon_{m}-\frac{3+2 \nu-\nu^{2}}{\pi E_{m}} \int_{0}^{l / 2} \frac{\xi}{\xi^{2}-x^{2}} \tau(\xi) d \xi
$$

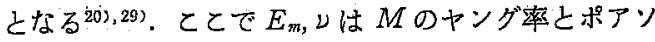
ン比, $\varepsilon_{m}$ 住一様応力 $\sigma_{m}$ による伸び歪みで $\varepsilon_{m}=\sigma_{m} / E_{m}$ である. 一方において，繊維 $(F)$ の $x$ 点の $x$ 方向伸 び歪みは

$$
\begin{aligned}
F & : \varepsilon(F)=\frac{1}{E_{f} A_{f}} \int_{x}^{l / 2} 2 \tau t d \xi \\
& =\frac{2 t}{E_{f} A_{f}} \int_{x}^{1 / 2} \tau(\xi) d \xi
\end{aligned}
$$

ここで，先の仮定 $M$ あ $F$ も相対的すべりはないとす ると

$$
\varepsilon(M)=\varepsilon(F) \quad 0 \leq x \leq l / 2
$$

(11)，(12)，(13)より，つぎのような $\tau$ の積分方程式が 得られる。

$$
\int_{0}^{1} \frac{u}{u^{2}-p^{2}} \tau(u) d u+\lambda \int_{p}^{1} \tau(u) d u=c
$$

ここで

$$
\left.\begin{array}{l}
x /(l / 2) \equiv p, \quad \xi /(l / 2) \equiv u \\
\lambda=\frac{\pi}{3+2 \nu-\nu^{2}} \cdot \frac{E_{m} t l}{E_{f} A_{f}}, \quad c=\frac{\pi}{3+2 \nu-\nu^{2}} \sigma_{m}
\end{array}\right\}
$$

\section{との積分方程式を数值例}

$$
\begin{aligned}
& E_{f}=1,400, \quad E_{m}=350 \mathrm{~kg} / \mathrm{mm}^{2}, \nu=0.3 ; \\
& l=50, \quad t=1 \mathrm{~mm}, A=1 \mathrm{~mm}^{2}
\end{aligned}
$$

について数值的に解き第 8 図を得た。ての解析では $F$ の両端末には $M$ から力が働かないよしている. 界面 剪断応力 $\tau$ は纎維端末で局所的仗大き，内方へ入る 之急減し，それに応じて織維応力 $\sigma_{f}$ は飽和する. と の $\sigma_{f}$ の分布形はきわめて典型的なすのである. てれ らの分布は基材の特性 $\lambda, c$ 亿依存する（b）はマトリ クス内の襶維のすぐ外側と， $x$ 軸上の応力 $\sigma_{x}(x, 0)$ の 分布之, 対称 $y$ 軸上の $x$ 方向応力 $\sigma_{x}(0, y)$ の分布を $\sigma_{m}$ との比で表わす. との $\sigma_{x}(x, 0) / \sigma_{m}$ の分布は, KELLY-TYSON (1965) ${ }^{14)}$ がその後 3 次元的に類推した あのと同形である.

$\sigma_{x}(x, 0)$ は織維端末から原点内方へ近づくと濑増は するが，中央点ではな书依然として，一棁応力 $\sigma_{m}$ よ り小さい，一方瀻維は中点で $\sigma_{f} / \sigma_{m}=3.6$ で，マトリ ックスよりむ高い応力をうりるととがわかる。この間 の特性はャング率比 $E_{r} / E_{m}$ が FRP のように 10 20 となるに従って一層顕著になる. 中央対称断面 $(x$ =0）のマトリクス応力 $\sigma_{x}(0, y)$ はこの例では繊維長

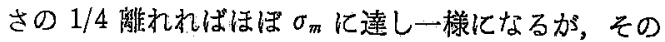

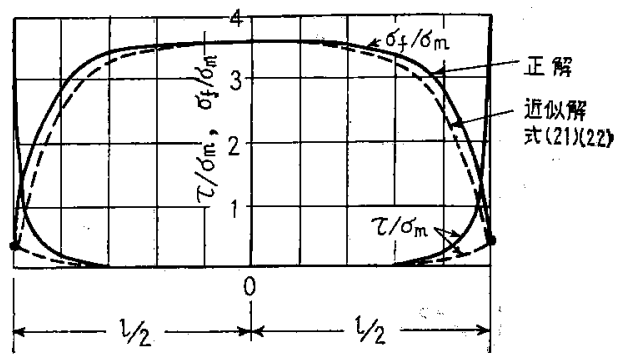

（a） 瀻維応力之瀻稚汇沿うせ九断応力の分布

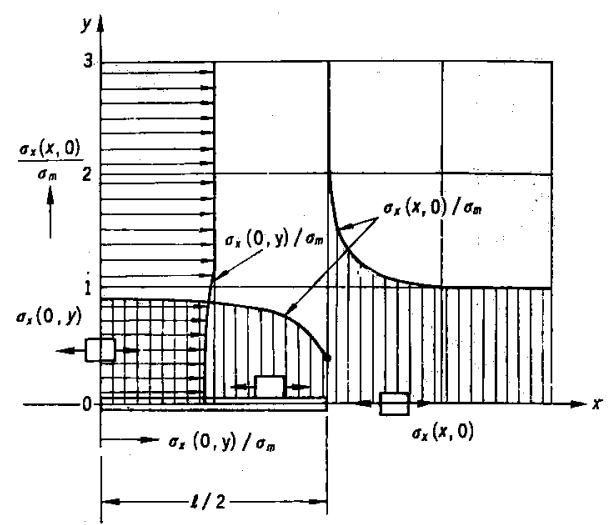

（b）マトリクス内の応力分布

第 8 図 数値例，緎維とマトリクス内の応力分布

分布の積分値と一様分布のそれとの差が緎維に伝達さ れたカになる。

なお， $\lambda, c へ$ へ依存性を近似的につ为むため

$$
\tau=\dot{a} \dot{u}^{n}
$$

と仮定して（14）に入机，その式を $p=0$ (中央点) で 満足させるように $a$ をきめると

$$
a=c /\left(\frac{1}{n}+\frac{\lambda}{n+1}\right)
$$

瀻維の引張応力は

$$
\sigma_{f}=\frac{1}{A_{f}} \int_{x}^{l / 2} 2 t \tau d x=\left(l t / A_{f}\right) \int_{u}^{1} \tau d u
$$

と表わされるからこ机に (16)，(17) を入れ

$$
\sigma_{f}(u)=\left(l t / A_{f}\right)\left[c /\left(\frac{n+1}{n}+\lambda\right)\right]\left(1-u^{n+1}\right)
$$

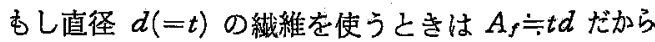
また $\nu=0.3$ とおいて (16), (17), (19) 加ら

$$
\begin{aligned}
\frac{\tau}{\sigma_{m}} & =\frac{(n+1) u^{n}}{\frac{E_{m} l}{E_{f} d}+\frac{n+1}{n} \cdot \frac{3+2 \nu-\nu^{2}}{\pi}} \\
& =\frac{(n+1) u^{n}}{\frac{E_{m} l}{E_{f} d}+1.12\left(\frac{n+1}{n}\right)}
\end{aligned}
$$

$n=4$ とおくと

$$
\frac{\sigma}{\tau_{m}}=\frac{5}{\frac{E_{m} l}{E_{f} d}+1.40} \cdot u^{4}
$$


また

$$
\frac{\sigma_{f}}{\sigma_{m}}=\frac{l}{d} \cdot \frac{1}{\frac{E_{m} l}{E_{f} d}+1.40}\left(1-u^{5}\right)
$$

をうる，ての結果は㵶維アスペクト比 $(l / d)$ 之基材の 弾性係数比 $E_{m} / E_{f}$ を含む，きわ力て簡単な実用式で ある. $l \gg d$ (連続長䋐維) の場合には $\tau \rightarrow 0, \sigma_{f} / \sigma_{m} \fallingdotseq$ $E_{f} / E_{m}$ となり合理的である.乙れは著者の求めた式で ある33).

グラス瀻維とエポキシ樹脂の組み合わせでは $E_{m} / E_{f}$ $=1 / 20$ であり, また $d=9 \mu, l=1 \mathrm{~mm}$ の場合には， $n=4$ のとき $\left(\tau / \sigma_{m}\right)_{\max }=0.72,\left(\sigma_{f} / \sigma_{m}\right)_{\max }=16.0$ とな る. これは $\tau, \sigma_{f}$ ともかなり大きい，なお $n$ のみを 5 , $6,7,20$ と変えると $\left(\tau / \sigma_{m}\right)_{\max }=0.87,1.02,1.17,3.12$, $\left(\sigma_{f} / \sigma_{m}\right)_{\max }=16.1,16.2,16.3,16.5$ となり，nkよっ ては最大䄉維応力はほとんぞ変わらないが，端末の最 大剪断応力が $0.72 \sim 3.20$ とかなり変わる. この例で は実際の $\tau$ の分布には高次近似 $(n \doteqdot 20)$ が近いようて ある.

つぎに 3 次元モデルによる解析については Dow ${ }^{232}$ の研究があるが，その思想に不明な点と間違いがある のでととに著者の考えを交え誤りを正して紹介する。

一方向強化材の中に各繊維を包含するマトリクス円 筒を考え，その一単位として第 9 図（a）をとる。これ は長さ $l$, 径 $d$ の㵶維 $(F)$ が, 直径 $D$ なる同心マト リックス円筒 $(M)$ 亿接着されており，外筒 $M$ 亿一様 引張応力が両端にかかる．このとき界面剪断応力 $\tau_{0}$ 之䄉維応力 $\sigma_{f}$ を求める. 界面牦㗢く前断応力 $\tau_{0}$ の影 郞は界面から $M$ 内にも $F$ 内にも及び，内部でも剪断 変形がおこる. 同時に $M, F$ 円筒は軸荷重をうける. そこでての音断変形に関与する部分は $M$ 円筒では界 面 $A_{0} B_{0}$ 加ら円 $C_{m}$ まで， $F$ 円筒では界面 $A_{0} B_{0}$ 加 ある円 $C_{f}$ までの領域であるとする(第 9 図(b). この $C_{m}, C_{f}$ 月としては，第 9 図(b) のように，断面の扇形 部分 $A_{0} B_{0} B A ， O A_{0} B_{0}$ の面積の重心の轨跡をとるこ 上ができる．そのおのおのに働く軸力は $C_{m}, C_{f}$ 上に 沿い墈〈からである．界面 $A_{0} B_{0}$ 加ら円 $C_{m}, C_{f}$ まで
の距離 $p_{m}, p_{f}$ は

$$
p_{m}=\frac{1}{3}\left(D^{3}-d^{3}\right) /\left(D^{2}-d^{2}\right)-\frac{d}{2}, \quad p_{f}=\frac{d}{6}
$$

$F$ の中央断面加左方に $x$ 軸をとり， $x$ 断面において， $M, F$ 各円筒の $C_{m}, C_{f}$ 上および界面上の点の軸変位 を $u_{m}, u_{f}, u_{0}$ とする. これらはいずれる軸対称変位で ある。

$x$ 断面は変形後第 9 図 (c) のようになり $u_{m} u_{0}$ 加ら $M$ 内に $u_{0} u_{f}$ から $F$ 内にそれぞれ剪断歪み $\gamma_{m}, \gamma_{f}$ を， したがって界面斯断応力 $\tau_{0}$ をひきおこす。

$$
\begin{cases}\gamma_{m}=\left(u_{m}-u_{0}\right) / p_{m}, & \gamma_{f}=\left(u_{0}-u_{s}\right) / p_{s} \\ \tau_{0}=G_{m} \gamma_{m}, & \tau_{0}=G_{f} \gamma_{s}\end{cases}
$$

$M, F$ 各円筒の $x$ 断面に偟く軸力を $P_{m}, P_{f}$ とする 之，乙机らと界面剪断応力との釣合加ら

$$
\left.\begin{array}{l}
d P_{m} / d x-\tau_{0} 2 \pi r=P_{m}^{\prime}-\tau_{0} 2 \pi r=0 \\
P_{f^{\prime}}+\tau_{0} 2 \pi r=0
\end{array}\right\}
$$

各内筒の断面積を $A_{m}, A_{f}$ ，ヤング率を $E_{m}, E_{f}$ とす ると

$$
P_{m}=E_{m} A_{m} u_{m}^{\prime}, \quad P_{f}=E_{f} A_{f} u_{f}^{\prime}
$$

(24)〜(26) から $u_{m}, u_{f}$ 以外の量を消去し次式を得る.

$$
\left\{\begin{array}{l}
u^{\prime \prime}{ }_{m}-\frac{\pi d}{E_{m} A_{m}}\left[\frac{G_{m} G_{f}}{p_{m} p_{f}} /\left(\frac{G_{m}}{p_{m}}+\frac{G_{f}}{p_{f}}\right)\right]\left(u_{m}-u_{f}\right)=0 \\
\left.u^{\prime \prime}{ }_{f}+\frac{\pi d}{E_{f} A_{f}}\left[\frac{G_{m} G_{f}}{p_{m} p_{f}}\right)\left(\frac{G_{m}}{p_{m}}+\frac{G_{f}}{p_{f}}\right)\right]\left(u_{m}-u_{f}\right)=0
\end{array} .\right.
$$

これらの差をつくると

$$
\left(u_{m}^{\prime \prime}-u_{f}^{\prime \prime}\right)-k^{2}\left(u_{m}-u_{f}\right)=0
$$

ここで

$$
\left.k^{2}=\pi d\left(\frac{1}{E_{m} A_{m}}+\frac{1}{E_{f} A_{f}}\right) \frac{G_{m} G_{f}}{p_{m} p_{f}}\right)\left(\frac{G_{m}}{p_{f}}+\frac{G_{f}}{p_{f}}\right)
$$

（28）を解いて

$$
u_{m}-u_{f}=A \sinh k x+B \cosh k x
$$

境界条件は $M$ の端部引張力を $P, F$ の端部は自由之 して

$$
\left.\begin{array}{ll}
x=0 \text { にて } & u_{m}=u_{f}=0 \\
x=l / 2 \text { にて } & u_{m}^{\prime}=\frac{P}{E_{m} A_{m}}, \quad u_{f}^{\prime}=0
\end{array}\right\}
$$

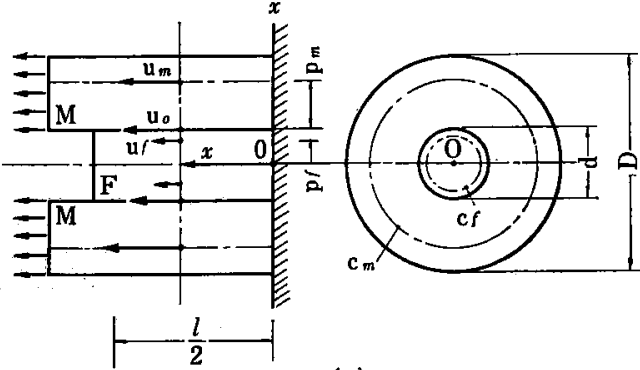

(a)

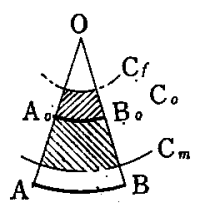

(b)

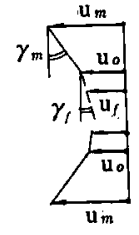

(c)

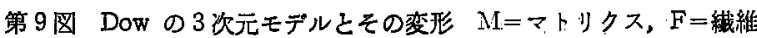


を満足するように $A, B$ をきめ

$$
\begin{aligned}
& u_{m}-u_{f}=\frac{P \sinh (k x / 2)}{E_{m} A_{m} k \cosh (k l / 2)} \\
& \tau_{0}=\frac{\lambda}{4} \cdot \frac{P \sinh (\lambda x / d)}{\left(A_{f}+\frac{E_{m}}{E_{f}} A_{m}\right) \cosh (\lambda l / 2 d)} \\
& \sigma_{f}=\frac{P}{A_{f}+\frac{E_{m}}{E_{f}} A_{m}}\left(1-\frac{\cosh (\lambda x / d)}{\cosh (\lambda l / 2 d)}\right)
\end{aligned}
$$

ここで

$$
\begin{aligned}
\lambda^{2}= & \frac{8}{3 \pi} \cdot \frac{G_{f}}{E_{f}}\left(1+\frac{E_{f} A_{f}}{E_{m} A_{m}}\right) /\left[1+2 \frac{G_{f} A_{f}}{G_{m} A_{m}}\right. \\
& \left.\times\left\{\left(1+\frac{A_{m}}{A_{f}}\right)^{3 / 2}-\left(1+\frac{3 A_{m}}{2 A_{f}}\right)\right\}\right]
\end{aligned}
$$

である。

以上の思想は一つのシア・ラグの考え方であること を著者は明らかにした。 また Dow は円 $C_{m}, C_{f}$ は断 面 2 次モーメントからきめていて正しくなく $k, \lambda$ の 值が間違っている. 以上の $\tau_{0} \gg \sigma_{f}$ の分布は closed form に書けていてわかり上い. 分布型は先の 2 次元 モデルの場合と全く同様になる.

一方, 光弾性解析法す $\mathrm{CM}$ の力学特性の研究に有 用であって，先に引用した光弾性実験研究は，単一緎 維まわりの応力分布をくわしくしらべており，上述の 弾性解析の結果をよく説明している.

以上は問題の弾性解であるが，KEILY-TYSON ${ }^{(4)}$ は， マトリックスが塑性域に入る場合を解析した，荷重を 大きくすると，マトリックスは㵶維端部から降伏を始 め，次第に塑性域を広げ，ついに全域が降伏する。 の状態では瀻維応力 $\sigma_{f}(x)$ は第 10 㘡 $(b)$ から

(a)

(b)

(c)

(d)

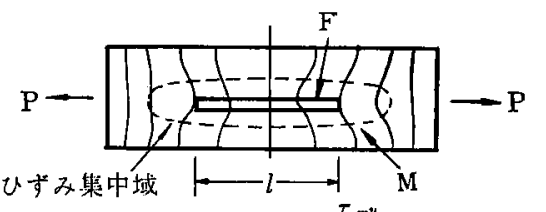

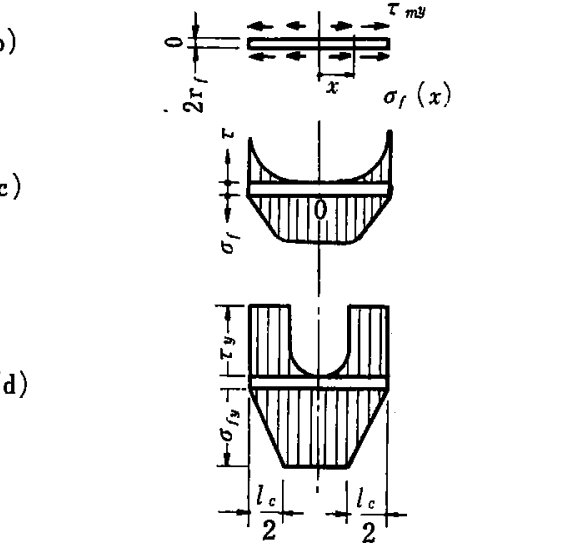

第 10 図 織維とマトリクスの相互作用

$$
\pi r_{f}^{2}\left(d \sigma_{f} / d x\right)=-2 \pi r_{f} \tau_{m y}
$$

これより $\sigma_{f}(l / 2)=0$ として

$$
\sigma_{f}=\frac{2 \tau_{m y}}{r_{f}}\left(\frac{l}{2}-x\right)
$$

もしも絨維がある場所から降伏点 $\sigma_{f y}$ に達して，塑性 流れをひき括てすときは $\sigma_{f}$ の分布は第 10 図 (d) のよ うになり， $\sigma_{f \max }=\sigma_{f y}$ となるような端末加らの距離を $l_{0} / 2$ 上すれば

$$
\left\{\begin{array}{l}
l_{c}=\left(\sigma_{f y} / 2 \tau_{m y}\right) d \\
\frac{l_{c}}{d}=\frac{\sigma_{f y}}{2 \tau_{m y}}
\end{array}\right.
$$

を得る. $l_{c}$ を瀻維の限界長さ (critical fiber length), $l_{e} / d$ を織維の限界アスペクト比 (critical aspect ratio) そいう. 䋐維が引張強さ $\sigma_{f t}$ まで弾性で以後塑性流れ を起こす材料では上式中の $\sigma_{f y}$ には $\sigma_{f t}$ を取ってよ い.

たとえばグラス・エポキシ FRP では $\sigma_{s t}=200 \mathrm{~kg} /$ $\mathrm{mm}^{2}, \tau_{m y}=2 \mathrm{~kg} / \mathrm{mm}^{2}$ なるとさは, $l_{c} / d=50$ となる. $d=10 \mu$ ならば $l_{c}$ は $500 \mu$ つまり $0.5 \mathrm{~mm}$ である. 峨 維を十分上く㗢かせるには繊維長 $l$ をこの限界長さ $l_{c}$ より大きくとらなければならない.

限界長さ $l_{c}$ よりむ長い等しい長さの瀻維をたくさ ん分散させた一方向強化枋では，各繊維が降伏点 $\sigma_{f y}$ 以後，完全塑性を示す場合には緎維の軸方向引張応力 の分布は第 11 四(b)のような台形になるのでその平均 軸応力として

$$
\sigma_{\mathrm{av}}=\left[\sigma_{f v} \cdot \frac{l_{c}}{2}+\sigma_{f v}\left(l-l_{c}\right)\right] / l=\sigma_{f v}\left(1-\frac{l_{c}}{2 l}\right)
$$

を得る、棒状材料の場合，任意横断面によって切られ

(a)

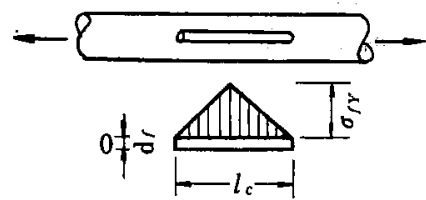

(b)

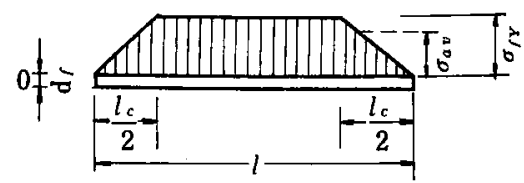

(c)

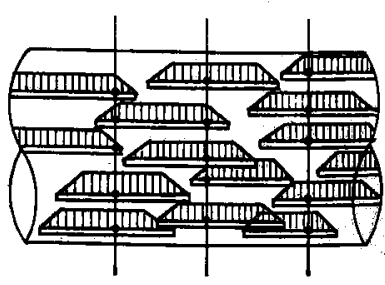

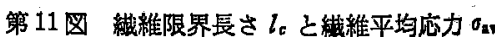


る瀻維数は平均としてどの横断面であ同じと考えてよ いから，織維の占める断面積 $A_{f}$ ，残りを $A_{m}$ とすれ ば， $A_{f}$ には一様に $\sigma_{\mathrm{av}}$ が， $A_{m}$ には応力 $\sigma_{m}{ }^{*}$ が偪く とすることができ，全断面 $A$ についての平均応力 $\sigma_{c}$ この釣り合い条件加ら

$$
\sigma_{c} A=\sigma_{\mathrm{av}} A_{f}+\sigma_{m} * A_{m}
$$

とかけ

$$
\sigma_{c}=\sigma_{f y}\left(1-\frac{l_{c}}{2 l}\right) V_{f}+\sigma_{m}^{*}\left(1-V_{f}\right)
$$

を得る、とれを短䋊維による複合材の引張強さに関す る複合則とよぶ. $\sigma_{m}^{*}$ は絨維の降伏ひずみに対応する マトリクス応力である.

第 12 図は $l / l_{c}$ をパラミターとする $\sigma_{c} \sim V_{s}$ 曲線で ある. $l / l_{c}=1$ のとき $\sigma_{c \max }=\sigma_{f y} / 2, l / l_{c}=50$ のとき $\sigma_{c \max }=0.99 \sigma_{f y}$ であり，連続紻維の場合に近つく. (38)式中 $l / l_{c} \rightarrow \infty$ のときは (38) は連続紪維の複合則 (6)と全く同じになる.

KELLY-TYSON は上の結果を確かめるため, 直径 0.2

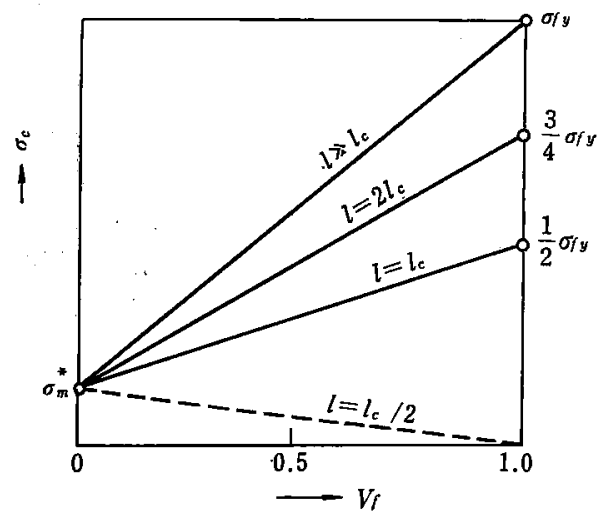

第 12 図不連続瀻維による一方強化材の複合則

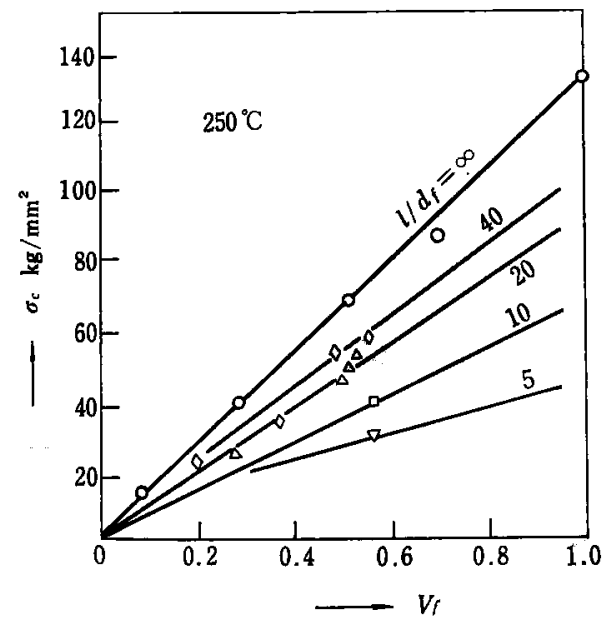

第13図 不連続タングステン線による一方向強化銅 の複合則に関する実験 (温度 $250^{\circ} \mathrm{C}$ )

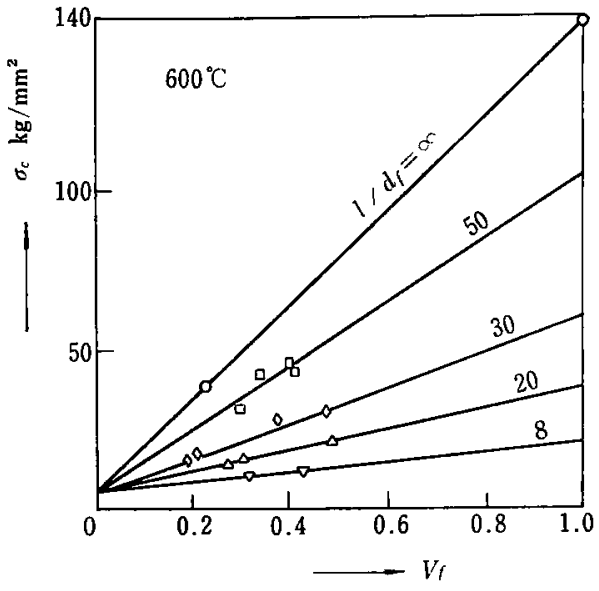

第 14 図 不連礼タングステン線による一方向強化銅 の複合則関する実験 (温度 $600^{\circ} \mathrm{C}$ )

$\mathrm{mm}$ のW 線によって銅を強化した複合材料によって 紻維了スペクト此 $l / d$ を種々に変えた場合の $\sigma_{c} \sim V_{f}$ を実测し第 13,14 図を得た。これらは複合則をよく実 証した ${ }^{14)}$.

2.3 実験的に限界アスペクト比 $l_{\mathrm{c}} / d$ と界面剪断強 度 $\tau$ を求める方法

1）限界アスペクト比 $\boldsymbol{l}_{\mathrm{c}} / \boldsymbol{d}$ KELLY-TYSON ${ }^{14)}$ は復 合則 (38)

$$
\sigma_{c}=\sigma_{f v}\left(1-\frac{l_{c}}{2 l}\right) V_{f}+\sigma_{m} *\left(1-V_{f}\right)
$$

を $V_{f}$ にて政分して得られる関係

$$
\frac{d \sigma_{c}}{d V_{f}}=\left(\sigma_{f y}-\sigma_{m}^{*}\right)-\frac{\sigma_{f y} l_{c}}{2 d} \cdot\left(\frac{d}{l}\right)
$$

を利用して $l_{c} / d$ を求める方法を提案している．つま り種々の $V_{f}$ に対する複合材の引張強さ $\sigma c$ の資料を まず求めておき，それから $d \sigma_{c} / d V_{f}$ を実験值から計 算し，それと $d / l$ とをプロットすると， $d / l$ の原点に おけるその曲線の slope から， $\sigma_{f y} l_{c} /(2 d)$ つまり $l_{c} / d$ が求められる.

KELLY-TYSON ${ }^{14)}$ の W-Cu についての実験結果の 第 1 表は $l_{c} / d$ と界面豚断強さ $\tau$ を示す.

なお $l_{c} / d$ を求めるのには引抜試験 (pull-out test) が利用される、強化用㵶維（または線）の先端をボタ ン状のマトリクスにあけた孔へ通し溶融マトリクス材

\begin{tabular}{|c|c|c|c|}
\hline \multirow{2}{*}{$\begin{array}{c}\text { 温 度 } \\
T^{\circ} \mathrm{C}\end{array}$} & \multicolumn{2}{|c|}{$\begin{array}{l}d \sigma_{c} / d V_{f} \text { 対 } d / l \text { 渑線の初 } \\
\text { 期スロープから求めた }\end{array}$} & \multirow{2}{*}{$\frac{\begin{array}{l}\text { 引拔き試験 } \\
\text { か心 }\end{array}}{\tau(k s i)}$} \\
\hline & $l_{\sigma} / d$ & $\tau(k s i)$ & \\
\hline 250 & 13.5 & 6.9 & 16.9 \\
\hline 300 & 19.3 & 5.9 & 15.1 \\
\hline 600 & 31.2 & 3.2 & \\
\hline
\end{tabular}

第 1 表 KELLY-TYSON の W-Cu 一方向強化材の実験加 ら $l_{c} / d$ 之界面剪断強さを求めた結果 $\mathrm{W}: 0.5 \mathrm{~mm} \phi$ 線 
をその間隙に注入してかためたのち，ボタンをおさえ て叔いて，緎維（線）を引き抜くのである、ボタンの 厚さ $(l)$ を種々にとり，引抜力 $P$ 老测定すると， $P$ 〜 $l / d$ のプロットができる. $d$ 一定とし $l$ をさいあの から大きい方へ変えていくと，Pは初め小さく，次第 に増して，ついに飽和しはぼ一定値に近づく。その遷 移する初めの点の $l / d$ をよめば，それが限界アスペク 卜比 $l_{c} / d$ を与える. 引抜荷重からは界面甥眑強さ $\tau$ む求められる。

2）界面剪断強さ $\tau$ 上述のボタン式引抜試験から $\tau$ を求めることができる.第 1 表の第 4 欄がその結果 であるが, 先の方法で求めたすのの約 2 3 倍大きく 出ている，微分の方法は精度を下げるので感心しな い.むしろ引拔試験法の方が実用性をすつ。

\section{3. 繰維強化材料の强度の方向性}

まず，一方向強化材の板の引張強さ，王縮強さ，そ の方向性を考察し，一般直交異方性材料の強度則を述 ベる.

3.1 一方向強化材の引張破壊モードと強さ 一方 向強化材の引張強さはきわわて強い方向性をもつこと はよく知られていたととであり，STOWELL-LIU ${ }^{31}$ ， TSAI ${ }^{48), 493}$ ，KELLY-DAVIES ${ }^{30)}$ ，林 ${ }^{332}$, 植村 - 山脇 ${ }^{34), 522}$ らの研究がある。

ある厚さの一方向强化材料の板を，繊維方向上角 $\theta$ をなす方向に引張る場合の強さをしらべる。つぎのよ うな種々の破壊モードがある。

3.1.1 緎維の破断による破壊 緎維に直角な断面 (第 15 図(b) の $B C$ ) について茾直応力がその方向の 引張強さ $F_{L}$ に達するときの平玸応力 $\sigma_{\sigma}$ を求めると

$$
\sigma_{a}=F_{L} / \cos ^{2} \theta
$$

3.1.2 マトリックスと繊維の界面剪断応力による 破罗 繊維に平行な断面 $A C$ (第 15 図(c)) に执いて， 㵶維方向の剪断応力が，この方向の尊断強さ $\tau_{1}$ に達 して破壊する場合であって，複合材としての強さは

(a)

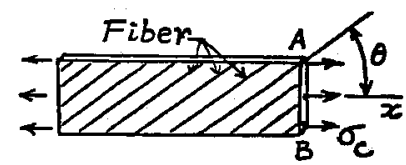

(b)

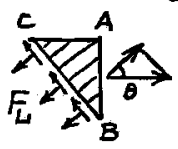

(c)

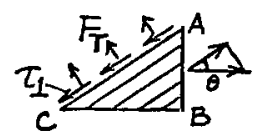

第 15 図 一方向強化材の破域様式

$$
\sigma_{c}=2 \tau_{1} / \sin 2 \theta
$$

3.1.3 マトリックスの引張破壊 第 15 図(c)より, 緎維に垂直な方向のマトリックス部の引張強さ $F_{T}$ に よって破壤する場合では,

$$
\sigma_{c}=F_{T} / \sin ^{2} \theta
$$

3.1 .4 繊維軸まわりの剪断による破壊 一方向強 化材の剪断強さとしては第 16 図(b)のように，䋐維方 向の竟断応力 $\tau_{1}$ のほか，それに直角な方向の鼻断応 力 $\tau_{2}$ に対するすのあある. 第 16 図 (a) のような引張 りにようて生ずる $\tau_{2}$ を求めるには角 $\varphi$ で与えられる 断面 $A C C^{\prime} D^{\prime}$ を考え，乙の断面上緎維方向の暃断店 力成分 $\tau_{1}$ とそれに直角方向の成分 $\tau_{2}$ とを求めればよ い. $\varphi$ は断面 $A C C^{\prime} D^{\prime}$ 之試験片側面 $A^{\prime} B^{\prime} C^{\prime} D^{\prime}$ と のなす角であり，乙れは $A ， A^{\prime}$ から $C^{\prime} D^{\prime}$ へ下した垂 線の足 $E$ に执いて $A E, A^{\prime} E$ の交角として与えられ る. いま, $\sigma$, 働いている断面 $A B B^{\prime} A^{\prime}$ 之, 考えて いる面 $A C C^{\prime} D^{\prime}$ の各面積を $A, F$ とすると,

$$
\left.\begin{array}{l}
\sigma_{c} A \cos \theta=\tau_{1} F, \quad A=F \sin \theta \sin \varphi \\
\sigma_{c} A \sin \theta \cos \varphi=\tau_{2} F, \quad \sigma_{c} A \sin \theta \sin \varphi=F_{T} \cdot F
\end{array}\right\}
$$

となり,とれから

$$
\begin{aligned}
& \sigma_{c}=\tau_{1} /(\sin \theta \cos \theta \sin \varphi) \\
& \sigma_{c}=\tau_{2} /\left(\sin ^{2} \theta \sin \varphi \cos \varphi\right) \\
& \sigma_{c}=F_{T} /\left(\sin ^{2} \theta \sin ^{2} \varphi\right)
\end{aligned}
$$

ここで $\tau_{1}, \tau_{2}, F_{T}$ はそれぞれの強さを表わすとすると, $\tau_{1}$ または $F_{T}$ による破壊は $\varphi=\pi / 2$ の断面で極小にな り，それは式 (41)，(42) と一致する。治によるすのは $\varphi=\pi / 4$ のとき最小となり

$$
\sigma_{c}=2 \tau_{2} / \sin ^{2} \theta
$$

(a)
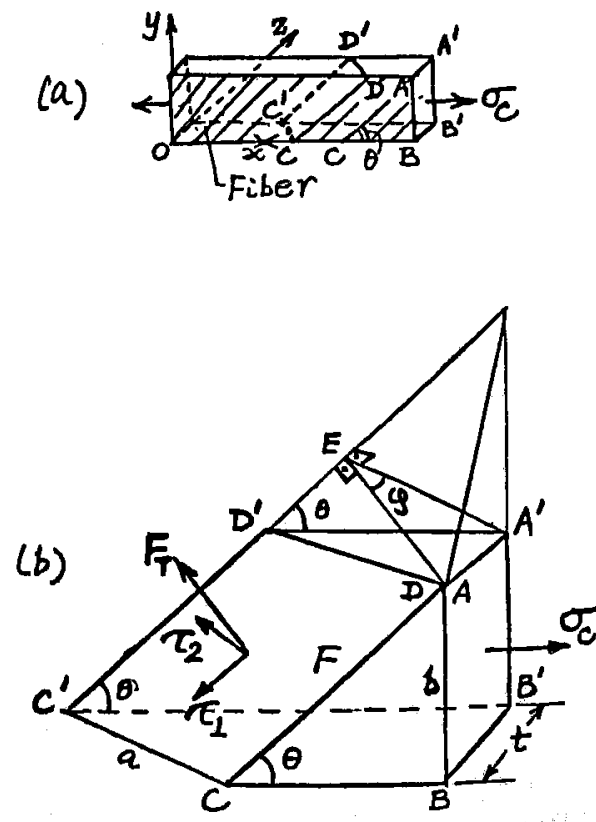

第 16 园 $\theta, \varphi$ にて与えられる緎維を含む平面 $\mathrm{CDD}^{\prime} \mathrm{C}^{\prime}$ K沿う萁断 $\tau_{2}$ 


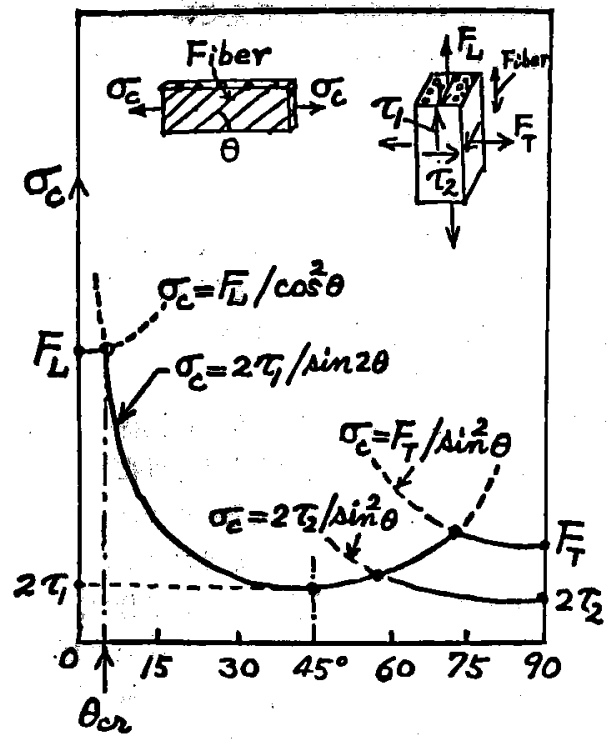

第 17 図一方向強化材の瀻維角 $\theta$ と強さの関係

となる. 普通 $\tau_{1}>\tau_{2}$ て， $\tau_{2}$ 自身がかなり小さい材料 では，この破壊様式は注意を要する．この結果は著者 の導いたものである。

第 17 図は以上の結果をまとめ $\sigma_{c} \sim \theta$ にプロットし たすのである.これらの最む下位に出る部分が起こり うる破買様式と破壤強さを与える．とれから，繊維の 破断による破壊を生ずる $\theta$ 範囲が非常にせまいとと がわかる. その限界角 $\theta_{\mathrm{cr}}$ は(40)己(41)の $\sigma_{c}$ を等置 して

$$
\theta_{\mathrm{cr}}=\tan ^{-1}\left(\tau_{1} / F_{L}\right)
$$

をうる，乙の限界角以上ではマトリクス部の剪断破罗 強さ $\tau_{1}, \tau_{2}$ または絨維に直角な方向の引張強さ $F_{T}$ に よる破壊を生ずる， $\theta_{\mathrm{cr}}$ は普通 $5^{\circ} \sim 10^{\circ}$ である.

植村らは一方向材，一方向巻き楾巻円筒の各種荷重 に対する強度実験（軸方向引張り，王縮，挨り）を行 ない興味ある結果を得ている.

3.1 .5 微視力学的考察の必要性 以上では，各断 面に現われる応力の分布はすべて “一様”であるとし ているが，このことは試験片の両端つかみ部とか，自 由迟の近傍において必ずしも一様でない，のみなら ず, 各種強さ $F_{L}, F_{T}, \tau_{1}, \tau_{2}$ などは “平均的強さ”で あって，局部的な微視的なあのをすへてて平均した結果 の值を意味するにすぎない．分散した蟣維とマトリク スの力の授受の機棈や, 内部クラックの伝播, 粘弾性 的振舞, 異方性の影辢, 初期応力などマイクロメカ二 ックス (micromechanics) の理論とその実験法特に顕 㮹光弾性手法の開発による解明の必要をここに強調し ておきたい(8),22),27),28).

3.1 .6 確率論的強度論 これについては, ROSEN,

CORTEN, BAscom, PAUL, KIES $ら^{35) \sim 40)}$ らの研究があ る.との理論は破壊の確率過程を説明するのが目標で ある. 一方向強化プラスチックスでは最終破壊が， ラ ンダムな㵶維の破断と樹脂の割れとの絮皘の結果とし て起こる．㵶維の破壊とマトリックスの破壊という二 つの破壊の連鎖䍐象の研究が必要亡なろう，との破壊 理諭はまだ発展の途上にある.

3.2 一方向強化材の压縮強さ Dow は, 繊維がま わりのマトリックスによって弾性支持された細い柱之 して压縮荷重に堪えること，圧縮破壊が，そうした細 い柱の座屆によって起とるととを初めて指摘した。し かし Dow は解析は行なわなかった。

その後 RosEN ${ }^{411}$ は第 18 図のように規則的に並ん だ柱をもつ CM 材料が圧縮によって起こる座届を(a) 伸張モードと (b) 剪断モードの 2 つに分け，弾性支持 をうける板状の柱として座届解析を行ないつきの結果 を得ている.

(a)の伸張モード (extenional mode) に対し，平均 圧縮強さとして

$$
\sigma_{c}=2 V_{f}\left[V_{f} E_{f} E_{m} / 3\left(1-V_{f}\right)\right]^{1 / 2}
$$

(b) の剪断モード (shear mode) に対しては圧縮強 さとして

$$
\sigma_{\varepsilon}=G_{m} /\left(1-V_{f}\right)
$$

を得ている.

この結果を第 19 図の $E, S_{1}$ として示す. $S_{2}$ は, 㵶

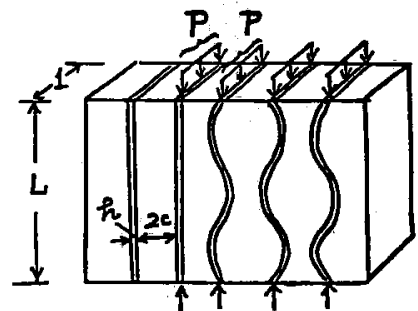

(a) 伸張モード 第18図 ROSEN のモデルと座屈モード

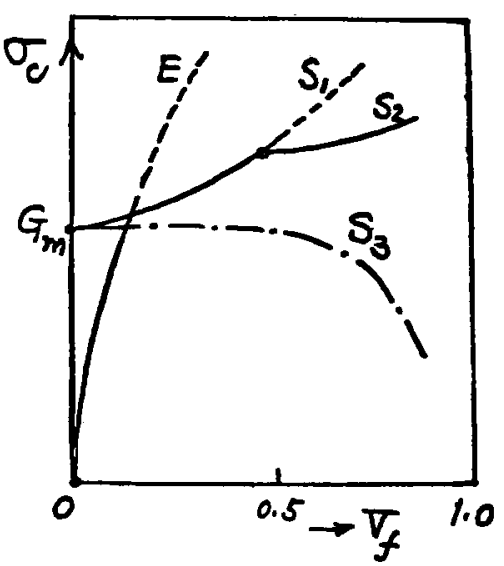

第19図一方向強化材の圧縮強さ $\sigma_{c}$ の 座属形式と $V_{f}$ との関係 
維の弾性限界を越えた効果を考慮に入れた曲線であり 途中から $S_{1}$ より枝分れしている.ての結果は実験と 余りよく一致しない.

林 22 2 -44) 仕剪断変形を伴う 王縮不安定に関する研究 加次式を提案している.

$$
\sigma_{\mathrm{cr}}=G_{m}
$$

たとえば第 20 図(a)のような四辺を剛な部材のピン結 合によって囲まれた厚さ $t$, 剪断弾性係数 $G$ の“新断 壁”(剪断だけをとる板場)をあつモデルについて，圧

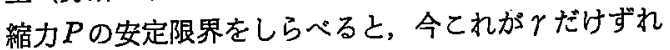
た位置に対するポテンシァル・エネルギーの変化を 0 とおき

$$
\frac{1}{2} G \gamma^{2} a b t-\frac{P}{2} a(1-\cos \gamma) \times 2=0
$$

$r$ は小さいとして, 座届荷重

$$
P_{\mathrm{cr}}=G b t, \quad P_{\mathrm{cr} r} / b t=G
$$

を得た．さらに木材角柱のような場合(第20図 (b) に む(c)のようなずれ不安定を示す圧縮応力

$$
\sigma_{\mathrm{cr}}=G_{m}
$$

を得た。最近 FOYE ${ }^{45)}$ は別の考えで同様な式を導いた
が彼は $G の \sigma_{c}$ 依存性などは考えていない，林は多く の材料について $G$ は圧縮応力 $\sigma$ の関数であることか ら

$$
\sigma_{\mathrm{er}}=G_{m}\left(\sigma_{\mathrm{cr}}\right)
$$

を得た．複合材のマトリックスがてのような不安定限 界汇達したとすると，瀻維を直線状保つ能力を失う ので, 緎維は横に倒れるか, とすにずれ破壊を誘起し て破懐導く、つまり压縮強さは

$$
\sigma_{c}=G_{m}\left(\sigma_{c}\right)
$$

にて与えられる. 第 19 図の $S_{3}$ がての関係を示す. 、 トリクスの剪断弾性率の圧縮応力依存性については資 料がほとんざない。ただての理論を裹づけする最近の 牧の研究 ${ }^{46)} 引$ 用したい，牧はポリエステル臌脂とグ ラス・ロービングから一方向巻きの板を作り，瀻維方 向の曲げ試験を行ない，曲げ強さ $\sigma_{b}$ を求めた. 一方 ポリエステル樹脂だけの注型円筒を作り挨り試験を行 なって $G_{m}$ を測定した. とれら2つの実験を, 種々の 硬化時間に対して系統的に行ない第21図を得た. 横軸 は $20^{\circ} \mathrm{C}$ における硬化時間である. この図には ROSEN のシアモードの式(46)もプロットしてある．との結果

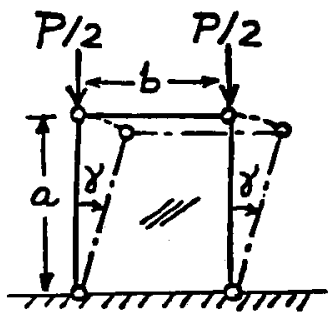

(a)ずね水不安定モデル

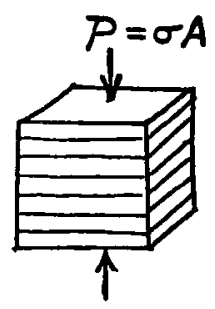

(b)

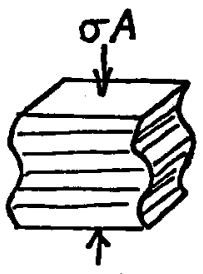

(c)

第 20 図 圧縮によるシア不安定現象

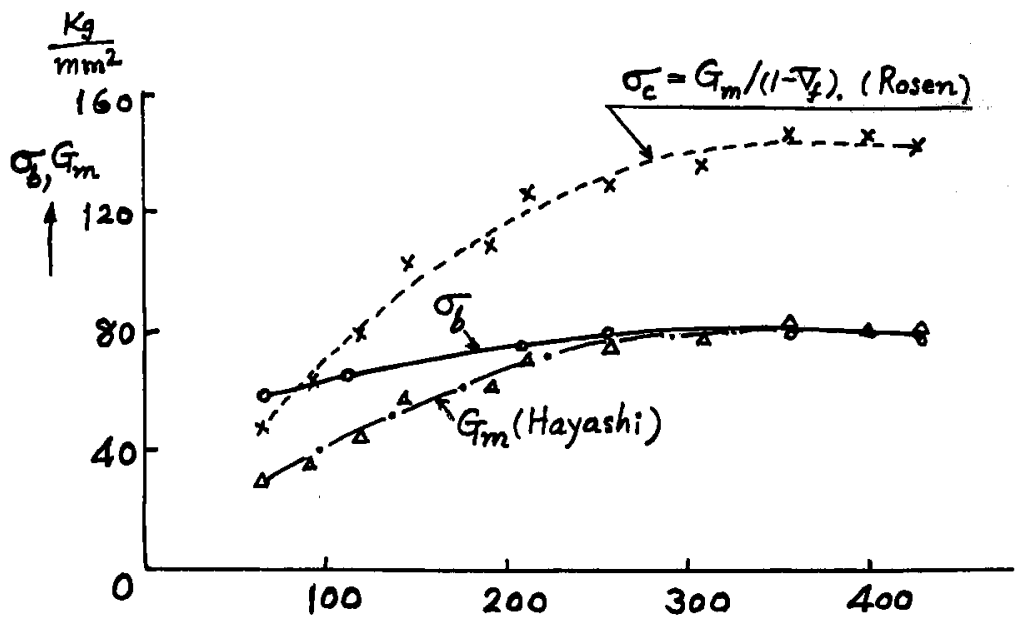

第 21 区 Glass-roving-Polyester 一方向巻き板の曲げ強さ $\sigma_{b}$, Polyester 注型品の $G_{m}$ と硬化洔間 (hr) 
は曲げ強さ $\sigma_{b}$ と $G_{m}$ とは硬化時間の広い領域に亘っ て非常によく一致したが ROSEN とは大きい照隔を示 した. 一方向強化材の曲げ破壊が曲げによる圧縮側の

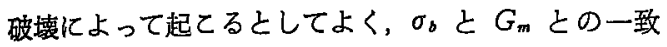
は，氐縮破塤に対する(51)式の正当性を示するのと考 えてよい.

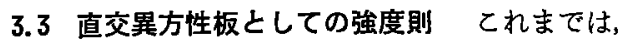
一方向強化材の考察を行なったか，一方向材の皘層 板,グラスクロス皘層板, フィラメント・ワインディ ング材などの中で “直交異方性材料”として取り扱え るすのが多数見受けられる.つぎててらの材料に対 する巨視的強度理論を考えよう. ての巨視的理論は, 現象論的接近に基碄をおくすのであって, 変形や破壊 の形式については直接には論及しない，そうして一つ の降伏とか破壊に対する規範を立てるあのである。よ

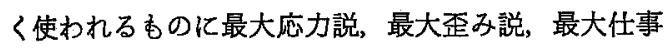
説がある. 今まで述べたものは最大応力説であった. つぎには組み合わせた応力にも適用できる最大仕事説 亿基づく強度則を述べる.

3.3.1 一様材犋の直交異方性材料の強度則 HILL ${ }^{47)}$ は等方性材料仁対する MISES の最大仕事説を直交異 方性材料に搪張したが，それを一方向強化材に適用し

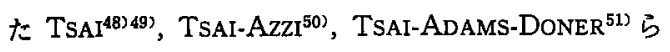
の研究か゚あり，さらに MISES の降伏条件をより一般 化した最近の HOFFMAN ${ }^{52)}$ の研究がある.

直交異方性対称軸方向に $X Y Z$ 軸をとり，それに関 する応力成分を $\left(\sigma_{X}, \sigma_{Y}, \sigma_{Z}, \tau_{Y Z}, \tau_{Z X}, \tau_{X Y}\right)$ とすると， MISES 則を拡張した HILL の降伏条件（最大仕事条 件) は

$$
\begin{gathered}
F\left(\sigma_{Y}-\sigma_{Z}\right)^{2}+G\left(\sigma_{Z}-\sigma_{X}\right)^{2}+H\left(\sigma_{X}-\sigma_{Y}\right)^{2} \\
\quad+2 L \tau_{Y Z^{2}}+2 M \tau_{Z X^{2}}+2 N \tau_{X Y}{ }^{2}=1
\end{gathered}
$$

と表わされる. F〜 $N$ は異方性を表わす係数で，乙れ らは $X Y Z$ 方向 (主方向ともよふ）の単軸引張降伏点 応力 $X, Y, Z$ およびそれらの間の禀断降伏点応力 $U$, $V, W$ によって表わされる. $X Y Z$ 方向にそれぞれ単 独に $\sigma_{X}, \sigma_{Y}, \sigma_{Z}$ をかけた場合は，それぞれ

$$
\begin{aligned}
& (G+H) X^{2}=1, \quad(F+H) Y^{2}=1 \\
& (F+G) Z^{2}=1
\end{aligned}
$$

が成り立たなければならない。てれから

$$
\left.\begin{array}{l}
2 F=\frac{1}{Y^{2}}+\frac{1}{Z^{2}}-\frac{1}{X^{2}}, 2 G=\frac{1}{Z^{2}}+\frac{1}{X^{2}}-\frac{1}{Y^{2}} \\
2 H=\frac{1}{X^{2}}+\frac{1}{Y^{2}}-\frac{1}{Z^{2}}
\end{array}\right\}
$$

一方，愬断応力をそれぞれ単独にかけた場合から

$$
2 L=1 / U^{2}, 2 M=1 / V^{2}, 2 N=1 / W^{2}
$$

としてきまる. ある材料について実験によって $X 〜 W$

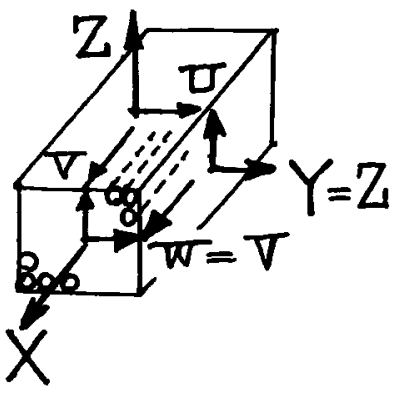

第 22 図一方向強化材，䋘維方向方 $\mathrm{X}$

の6 個の単一応力に対する強さが求められれば (53), (54)を(52)に入れて，任意の応力状態 $\left(\sigma_{X} \sim \tau_{X Y}\right.$ の 6 成分）に対する降伏条件が求められる.

一方向強化材料については，瀻維方向にX軸をとっ た場合, 特性は $Y Z$ 面内では等方性になるので

$$
X ; Y=Z, U ; V=W
$$

となり (第 22 図), 降伏条件は

$$
\begin{aligned}
& \frac{1}{2}\left(\frac{2}{Y^{2}}-\frac{1}{X^{2}}\right)\left(\sigma_{Y}-\rho_{Z}\right)^{2}+\frac{1}{2 X^{2}}\left(\sigma_{Z}-\sigma_{Z}\right)^{2} \\
& \quad+\frac{1}{2 X^{2}}\left(\sigma_{X}-\sigma_{Y}\right)^{2}+\left(\frac{\tau_{Y Z}}{U}\right)^{2}+\left(\frac{\tau_{Z X}}{W}\right)^{2}+\left(\frac{\tau_{X Y}}{W}\right)^{2} \\
& \quad=1
\end{aligned}
$$

となる。

航空・宇宙用構造では薄肉板材として使われる場合 が多い.つまり平面応力場の降伏条件を求めておくと 便利である. 面内に $X Y$ 軸を, 厚さ方向に $Z$ 軸をと ると

$$
\sigma_{Z}=\tau_{X Z}=\tau_{Y Z}=0
$$

として (52)，(53), (54)加ら

$$
\begin{gathered}
\left(\frac{\sigma_{X}}{X}\right)^{2}-\left(\frac{1}{X^{2}}+\frac{1}{Y^{2}}-\frac{1}{Z^{2}}\right) \sigma_{X} \sigma_{Y} \\
+\left(\frac{\sigma_{Y}}{Y}\right)^{2}+\left(\frac{\tau_{X Y}}{W}\right)^{2}=1
\end{gathered}
$$

$X$ 軸方向に䋐維を入れた一方向強化板の中央面内 飞 $X Y$ 面をとると, $X Y$ 面内の平面応力場 $\left(\sigma_{X}, \sigma_{Y}\right.$, $\left.\tau_{X Y}\right)$ に対して,

$$
\left(\frac{\sigma_{X}}{X}\right)^{2}-\frac{Y}{X}\left(\frac{\sigma_{X}}{X}\right)\left(\frac{\sigma_{Y}}{Y}\right)+\left(\frac{\sigma_{Y}}{Y}\right)^{2}+\left(\frac{\tau_{X Y}}{W}\right)^{2}=1
$$

を得る.(57) において $Y=Z$ とおけばよいからであ る. てれは(56)において平面応力場の条件（a)を入れ ても，もちろんての式が導かれる.

引張りと圧縮で暴なる強さをあつ材料では $\sigma_{X}, \sigma_{Y}$ の 正負に応じてそれらの強さを使い分けるととを TSAI が提案している:

$X Y$ を $L, T$ 方向, $X, Y, W$ を $F_{L}, F_{T}, S$ と書き変 えると(58)式は 


$$
\left(\frac{\sigma_{L}}{F_{L}}\right)^{2}-\frac{1}{r}\left(\frac{\sigma_{L}}{F_{L}}\right)\left(\frac{\sigma_{T}}{F_{T}}\right)+\left(\frac{\sigma_{T}}{F_{T}}\right)^{2}+\left(\frac{\tau_{L T}}{S}\right)=1
$$

となる.ととで

$$
r \equiv F_{L} / F_{T}, \quad s=F_{L} / S
$$

対称軸 $L T$ 上角 $\theta$ を标任意の直交座標軸 $(x, y)$ に関する平面応力 $\left(\sigma_{x}, \sigma_{y}, \tau_{x y}\right)$ に対する降伏条件は， それをまず等佂な $(L, T)$ 軸代関する応力状態 $\left(\sigma_{L}\right.$, $\left.\sigma_{T}, \tau_{L T}\right):$

$$
\left[\begin{array}{c}
\sigma_{L} \\
\sigma_{T} \\
\tau_{L T}
\end{array}\right]=\left[\begin{array}{ccc}
l^{2} & m^{2} & -2 l m \\
m^{2} & l^{2} & 2 l m \\
l m & -l m & \left(l^{2}-m^{2}\right)
\end{array}\right]\left[\begin{array}{c}
\sigma_{x} \\
\sigma_{y} \\
\tau_{x y}
\end{array}\right]
$$

飞直し，乙れを(59)に入れればよい（第23図）.

ここで $l=\cos \theta, \quad m=\sin \theta$.

以上で $F_{L}, F_{T}, S$ は降伏点としてきたが, 引張強さ 剪断強さを取ることもできよう.特に脆性破壊をする 材料ではそうとってよいし，他の材料でも近似的には 許されよう. 引張強さ $F_{L}, F_{T}$ は角 $\theta=0^{\circ}$ と $90^{\circ}$ 試験

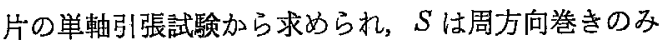
を手つ線巻き円筒の拱り試験から求められる．TSAI はグラス瀻維とエポキシ樹脂の一方向強化材について

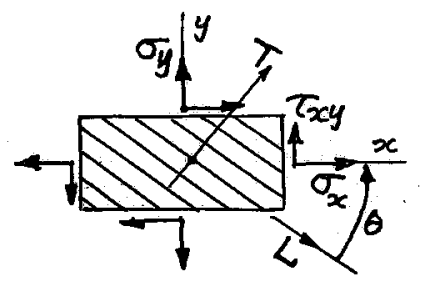

第23図

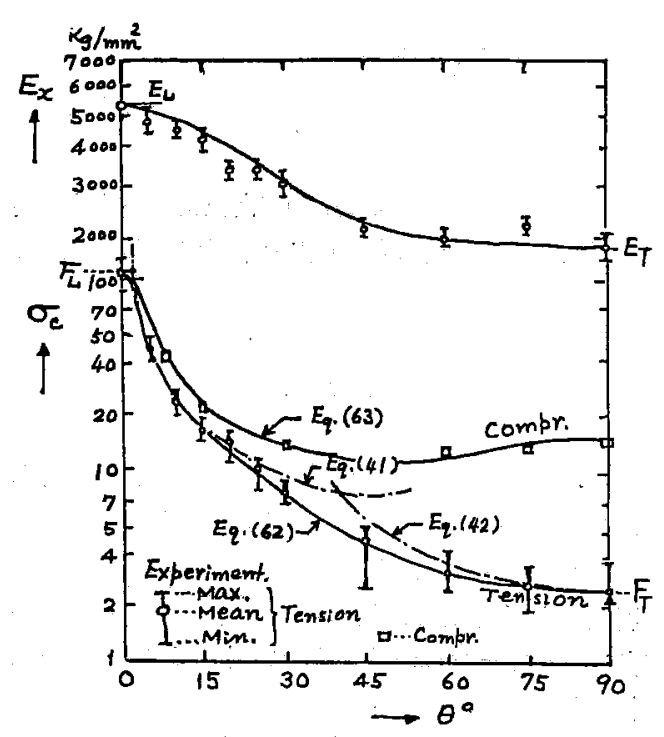

第 24 図一方向強化材の引張強さ，田縮強ざおよび弾性

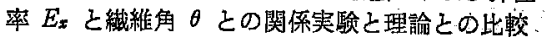

一連の実験を行ない上式を検証している：実測より

$$
F_{L}=105, F_{T}=2.8, S=4.2 \mathrm{~kg} / \mathrm{mm}^{2}
$$

をえた．種々の角度 $\theta$ に切った試験片の $x$ 軸方向引張 試験を行ない第 24 図を得ている。 $\sigma_{x}$ のみの場合の強 度則结上式加ら

$$
\left(F_{L} / \sigma_{x}\right)^{2}=l^{4}+\left(s^{2}-1\right) l^{2} m^{2}+r^{2} m^{4}
$$

でてれを同図実線で示してある.

一右に扔いて先に 3.1 で述べた強度則はこの例では

$$
\begin{aligned}
& \sigma_{c}=105 / \cos ^{2} \theta, \quad \sigma_{c}=8.4 / \sin (2 \theta) \\
& \sigma_{c}=2.8 / \sin ^{2} \theta
\end{aligned}
$$

であり，との関係を図中鎖線で示してある.図からわ かるように，これらの破壇法則，破壊形式は実験を。 く説明する. (62)式はこれらの包絡線状に出ており， 下界を与えている．とれらの公式では破壤形式は与え られない。

同図中には圧縮強さの実験值も示されているが，此 較の実線は， $L, T$ 方向の圧縮強さ $F_{L^{\prime}}, F_{T^{\prime}}$.を用いた 強度則 :

$$
\left(F_{L} / \sigma_{x}\right)^{2}=l^{4}+\left(s^{\prime 2}-1\right) l^{2} m^{2}+r^{\prime 2} m^{4}
$$

を示す．乙こで $r^{\prime}=F_{L} / F_{T^{\prime}}, s^{\prime}=F_{L^{\prime}} / S$ ，実測によ って得た $F_{L^{\prime}}=105, F_{T^{\prime}}=14, S=4.2 \mathrm{~kg} / \mathrm{mm}^{2}$ (先と 同じ）を用いている，圧縮の場合む実験值と公式とは よく一致する.

HoFman の方法 ${ }^{52)}$ : 最近 HOFFMAN は，引張り之 王縮とで強さが達う材料の強度則を，一つの式で表的 すと之を提案した. それには，(52) 式に， $\sigma_{X}, \sigma_{Y}, \sigma_{Z}$ の一次項を含ませて

$$
\begin{aligned}
& c_{1}\left(\sigma_{Y}-\sigma_{Z}\right)^{2}+c_{2}\left(\sigma_{Z}-\sigma_{X}\right)^{2} c_{3}\left(\sigma_{X}-\sigma_{Y}\right)^{2} \\
& \quad+c_{4} \sigma_{X}+c_{5} \sigma_{Y}+c_{6} \sigma_{Z}+c_{7} \tau_{Y} Z^{2} \\
& \quad+c_{8} \tau_{Z X}{ }^{2}+c_{9} \tau_{X Y}{ }^{2}=1
\end{aligned}
$$

を使えばよい， 9 個の $c_{i}$ は， $X, Y, Z$ 方向の引張, 王縮之それらの間の剪断の 9 個の単純応力に対する強 度 $F_{t X}, F_{c X} ; F_{t Y}, F_{c Y} ; F_{t Z}, F_{c} Z ; F_{s Y Z}, F_{s} Z X, F_{s} X Y$ 加 与えられれば，つぎのようにきまる．脚符 $t, c, s$ は引 張，王縮，剪断を表わす。

$$
\begin{aligned}
& c_{1}=\frac{1}{2}\left[\left(F_{t Y} F_{c Y}\right)^{-1}+\left(F_{t Z} F_{c z}\right)^{-1}\right. \\
& \left.-\left(F_{t X} F_{c X}\right)^{-1}\right] \\
& c_{2}, c_{3} \text { は上式の } X, Y, Z \text { の順列を変 } \\
& \text { えたあの. } \\
& c_{4}=\left(F_{t X}\right)^{-1}-\left(F_{c X}\right)^{-1}, c_{5}, c_{6} \text { 屯同栐 } \\
& c_{7}=\left(F_{s Y Z}\right)^{-2}, c_{8}, c_{9} \text { 手同様 }
\end{aligned}
$$

一方向強化材料の板の場合には，繊維方向 $(L)$ とそ 机任直角方向 $(T)$ を板面内にとるとき，平面応力 $\left(\sigma_{L}\right.$, $\left.\sigma_{T,} \tau_{L T}\right)$ 亿対する強度則之して (64)，(65) 加ら，次式 が導かれる。

$$
\frac{\sigma_{L}^{2}-\sigma_{L} \sigma_{T}}{F_{c L} F_{c L}}+\frac{\sigma_{T}^{2}}{F_{t T} F_{c T}}+\frac{F_{c L}-F_{t L}}{F_{t L} F_{c L}} \sigma_{L}
$$




$$
+\frac{F_{c T}-F_{t T}}{F_{t T} F_{c T}} \sigma_{T}+\frac{\tau_{L T}{ }^{2}}{F_{s L T}}=1
$$

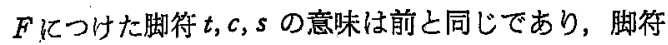
$L, T$ は対称軸方向 $(L, T)$ を意味する.

$(x, y)$ を $(L, T)$ に対し $\theta$ だけ傾いた任意直交座標 とし, $x y$ 座標に関する応力状態 $\left(\sigma_{x} \sigma_{y} \tau_{x z}\right)$ を, 主方 向 $(L, T)$ に関する等価な応力状態 $\left(\sigma_{L}, \sigma_{T}, \tau_{L T}\right)$ に変 換守る式(61)を式(66)に使うと, この $\left(\sigma_{x}, \sigma_{y}, \tau_{x y}\right)$ に 対する強度則が導かれる。

一方向強化グラス・エポキシ FRP 板の一例として $F_{t L}=110 \mathrm{~kg} / \mathrm{mm}^{2}, \quad F_{c L}=71, \quad F_{t T}=2$

$$
F_{c T}=14, \quad F_{s L T}=7 \mathrm{~kg} / \mathrm{mm}^{2}
$$

なる場合の，任意角 $\theta$ 方向の引張，圧縮強度を上式加 ら計算し，実駼結果と比較したのが第 25 図である. 計算では $\sigma_{y}=\tau_{x y}=0$ とし $\sigma_{x}$ の 2 次式が(66) 加ら得 られる. それより正負 2 根が求められて正值が引張， 負值が王縮強さを与えるのである.

なお，立断応力 $\tau_{x y}$ のみの場合をしらべて見ると， (61) 加ら

$$
\begin{aligned}
& \sigma_{L}=-2 l m \tau_{x y}, \quad \tau_{T}=2 \ln \tau_{x y} \\
& \tau_{L T}=\left(l^{2}-m^{2}\right) \tau_{x y}
\end{aligned}
$$

であるのでてれを(66)に入れ

$$
\begin{aligned}
& {\left[\frac{8 l^{2} m^{2}}{F_{t L} F_{c L}}+\frac{4 l^{2} m^{2}}{F_{t T} F_{c T}}+\frac{\left(l^{2}-m^{2}\right)^{2}}{F_{s L T^{2}}}\right] \tau_{x y}{ }^{2}} \\
& \quad+2 l m\left[\frac{F_{t L}-F_{c L}}{F_{t L} F_{c L}}-\frac{F_{t T}-F_{c T}}{F_{t T} F_{c T}}\right] \tau_{x y}=1
\end{aligned}
$$

てれに上記数値(67)を入れると

$$
\begin{aligned}
& {\left[7.05 l^{2} m^{2}+\left(l^{2}-m^{2}\right)^{2}\right]\left(\tau_{x y} / F_{s L T}\right)^{2}} \\
& \quad+6.07 \operatorname{lm}\left(\tau_{x y} / F_{s L T}\right)=1
\end{aligned}
$$

$l=\cos \theta, m=\sin \theta$ であり $\theta$ の種々の值に対する $\tau_{x y}$ を 計算すると，乙の場合にあ正負の值を得る。この場合 の角 $\theta$ は $L$ 軸加ら $x$ 軸へ anti-clockwise には加る方向 を正にとっているので, $\tau_{x y}>0$ の場合がいわゆる“逆 岦断” (inverse shear)， $\tau_{x y}<0$ の場合が “順剪断” (normal shear) に対応する．計算の結果を第 26 図に 示す. 直交異方性板の愬断にこの 2 種類が存在し, 両 者の違うことは，既に著者らの研究によって明ら汃に

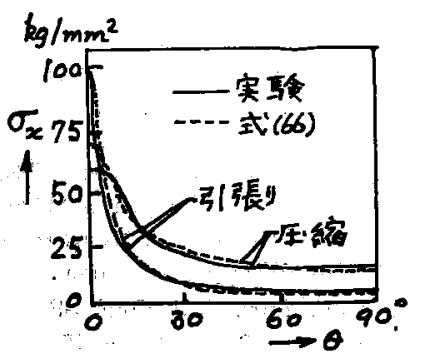

第25图一方向強化材の単純引張りおよび圧縮 強さと HoPrMAN の式の比较

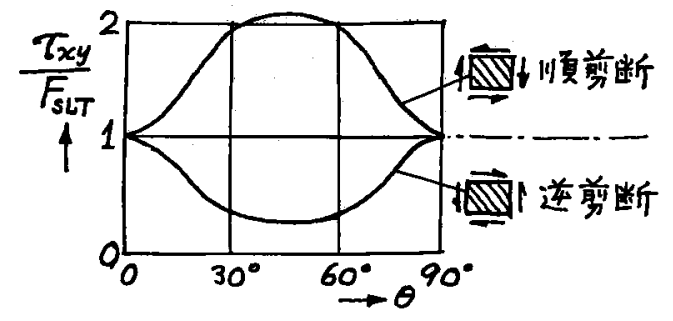

第 26 図順剪断と逆剪断強さ

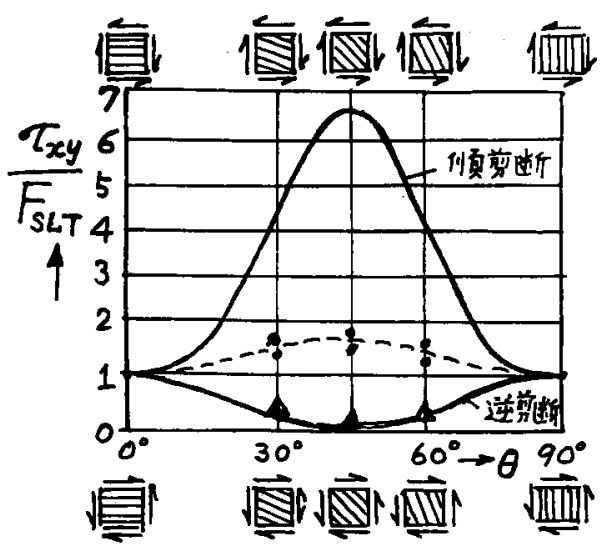

第 27 図順剪断と逆剪断の実験之計算

○, $\boldsymbol{\Delta}$ ……実験值

されているが，本例でも，図示のように方向によって 大差のあるととは注意を要すると同時に，興味あると とである.

植村らあグラス・ロービング・エポキシの一方向巻 き FM の強度をしらべており，

$$
\begin{aligned}
& F_{t L}=F_{c L}=55, \quad F_{t T}=1.5, \quad F_{c T}=8, \\
& F_{s L T}=4 \mathrm{~kg} / \mathrm{mm}^{2}
\end{aligned}
$$

を得ており，㨝り剪断実験値と比較している. 上式 (69) 之植村ら ${ }^{53)}$ の実験とを比較したのが第 27 図であ る. この場合，逆剪断の方はよく合うが順剪断の場合 が非常にくい違うのは，実験の力は座屈を伴うためと 考えられる.

いずれにしてあ荷重の方向が違う強度を，一つの式 で計算できるのが HOFFMAN の式の特長であろう。

TSAI の強度則などは，一方向強化材の板を何首か 皘屏して作った皘層板の面内荷重に対する強度や破壊 様式をしらべるのにあ役立つ. TSAI は直交三層積層 板の解析で，理論的に二イ現象 (Knee phenomena) の起こる解明と強度計算法を示し，引張破淁強度は実 験とよく一致することを見出した．そこでは各層でと に上述の強度則を適用したのである ${ }^{48), 49) . ~}$

な找積層板や直交異方性外板をもった一般の構造で は，座屆によって強度を失う可能性をもつ．座屈現象 は棈造力学の重要な課題であるがここではふれない。 


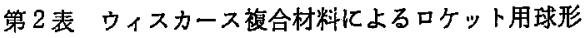
pressure vessel の軽量化予想

\begin{tabular}{|c|c|c|c|c|c|}
\hline 材 & $\begin{array}{l}\text { 比 } \\
\text { 電 } \\
r\end{array}$ & $\mid \begin{array}{c}\text { 引張強さ } \\
\sigma_{\mathrm{f}} \\
\mathrm{kg} / \mathrm{mm}^{2}\end{array}$ & $\begin{array}{c}\text { 弾性率 } \\
E \\
\mathrm{~kg} / \mathrm{mm}^{2}\end{array}$ & $\mid \begin{array}{cc}上_{-}-\text {引張 } \\
\text { 強 } \\
o_{t} / \tau \\
\mathrm{kg} / \mathrm{mm}^{2}\end{array}$ & 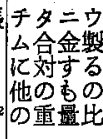 \\
\hline 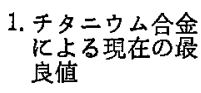 & 4.7 & 140 & 12,000 & 30 & 1.00 \\
\hline 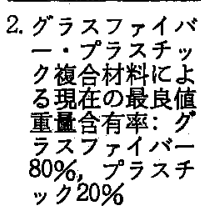 & 2.2 & 100 & 4,500 & 45 & 0.67 \\
\hline $\begin{array}{l}\text { 3. カーボン究敒 } \\
\text { カース複合材料 }\end{array}$ & 1. 7 & 600 & 60,000 & 350 & 0.09 \\
\hline
\end{tabular}

\section{4. 結 論}

FRP 加ら FRM ゃ FRR への繊維強化複合材料の 発展の過程を概観し, 瀻維強化機構と, 強化理論, 強 度理諭を概説したがなお他の力学特性についてもふれ るべきすのが少なくない，FRCM が，現在航空宇宙 工学において果しつつある整量化之, 耐熱性向上への 可能性は今後ますます重要性を増すととであろう，第 2 表は，現用の $T_{i}$ 材料，グラス・エポキシ線巻き材 料と, 将来十分の可能性をるって予見されるカーボ ン・フィラメント線巻き構造によるロケット・チャン バーの軽量化を示すむのである. 炭䒺䋐維による線巻 きは，近い将来現在の重量を $1 / 10$ にしてしまう。一 方, FRM 等耐熱材料の開発が急速にすすみつつあり， この 5 年後には Jet engine の耐熱部, SST 棈造の主 翼胴体構造材, 原子力関係耐熱構造材料として実用さ れる見通しである．強度理論もまた micromechanic s $_{\mathbf{S}}$ の進歩によってますます精密化されていくことであろ う.

\section{文献}

1) D.V. Rasato \& C.S. Grove: Filament Winding, Interscience Publisher (1964).

2) American Society for Metals 発行: Fỉber Composite Materials. (1965).

3) L. Holliday: Composite Materials, Elsevier Pub]. Comp. (1966).

4) G.S. HolsstrR \& C. Thomas: Fibre Reinforced Materials, Elsevier Publ, Comp. (1966).

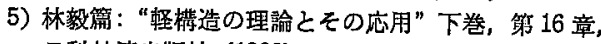
日科技連出版社 (1966).

6) L. J. Broutman \& R. H. KRock: Modern Composite Materials, Addison-Wesley Publ, Comp. (1967).

7) R. T. Schwartz and H.S. Schwartz: Fundamental Aspects of Fiber Reinforced Plastic Composites, Interscience Publisher. (1968).
8) L.R. McCreight, H.W. Rauch \& W.H. Sutton Ceramic \& Graphite Fibers and Winding (A survey of Technology) Academic Press. (1965).

9) S. S. Brenner, Jour. Appl, Physics. 27, 1484 (1956).

10) R.W. JECh, E.P. Weber \& A. D. Schwope, Met. Conf. Vol. II "Reactive Metals" Interscience Pub. (1959), p. 109.

11) D. L. McDanels, R.W. Jech. \& J.W. WeEton, "Metal Progress" 78 (Dec. 1960), 118.

12) D. L. McDanels, R.W. Jech. \& J.W. Weeton, "Stress-Strain Behavior of Tungsten-Fiber-Reinforced Copper Composite" NASA, TN, D-1881 (1963).

13) A. Kelly, Proc. Roy. Soc. A 282 (1964), 63.

14) A. Keliy \& W.R. Tyson "Fiber Strengthened Materials" High Strength Materials, 2nd International Materials Conference (1965) 578, Berkely, Calif. V.F. ZACKAY, ed. John Wiley \& Sons. Inc.

15) J.W. WeEton \& R.A. Signorelli, NASA, TND$3530,(1966)$.

16) A. Keliy \& G. J. Davies, Met. Rev. 10-37(1965), 1.

17) H. L. Cox, Brit. J. Appl. Physics, 3 (1952-3), 72.

18) T. Hayashr, Proc. of Symposium on "Non-homogeneity in Elasticity and Plasticity" in Warsaw (sponsored by IUTAM) (1958)) 501.

19）河田，日本航空学会誌 4, 31 (1956), 197.

20) T. HAYASH, Proc. 5th Inter. Symposium on Space Technology and Science, Tokyo (1963), 683.

21) T.Hayash, Proc. 4 th Inter. Symposium on Space Technology and Science, Tokyo (1962), 156.

22) 林，小山，近藤：日本航空学会法, 15 (1967)， 145.

23) N.F. Dow, General Electric Company, Mssile and Space Division, Report No. R 63 SD 61 (1963).

24) G. A. Horridge, Brit. J. Appl. Phys. 6 (1955), 314.

25) D. M. Schuster, \& E. Scala, Trans. Met. Soc. AIME 230 (1965) 1935.

26) J. Mullin, J. M. Berry \& A. Gatti, General Electric Tech. Inf. Series, R 67 SD 51 (1967).

27) 林: 応用物理, 31-10 (1962)，808.

28) 河田はか：第 2 回宇宙航空工学における FRP シンポ ジウム報告集 (1967-12)， 65.

29) S. Timoshenko., "Theory of Elasticity" McGrawHill (1936).

30) W. R. Tyson \& G. J. Davies, Brit. J. Appl. Phys. 16-2 (1965), 199.

31) E. Z. Stowoll \& T.S. Lru, J. Mech. Phys. Solids, 9-4 (1961), 242.

32) A. Kelly \& G. J. Davies. Met, Rev. 10-37(1965), 1.

33）林：日本機械学会誌，71-593 (1968-6).

34) 植村ほ加 2 名: 第 2 回宇宙航空工学におりる FRP シ ンポジゥム予稿焦 (1967-12).

35) B. W. Rosen, AIAA J., 2-11 (1964-11), 1965.

36) C. A. Bouc, Proc. 19 th Conf. SPI Reinforced Plastics Division (1964), Section 19-G.

37) H. T. Corten, "Micromechanics and Fracture Behavior of Composites," Chapter 2, "Modern Composite Materials" ed. by L. J. Broutman and R. H. Krock, Addison-Wesley Publ. Comp. (1967).

38) W.D. Bascom, Proc. 20 th Conf, SPI. Reinforced Plastics Division (1965), Section 15-B.

39) J. T. Paul Jr. \& J. B. Thompson, Proc. 20 th Conf. SPI Reinforced Plastics Dioision, (1965), 
Section 12-C

40) J. A. KIEs, U. S. Naval Research Labo Rep. 5763 (1962).

41) B. W. Rosen, General Electic Co. M. S. D. Technical Information Series, R64, SD 80 (1964).

42) 林，第 4 回応用数学および力学㜔演会（昭 24.7.24).

43) T. HAyAshI, Joint Meeting of AIAA, Roy. Aero. Soc and Japan Soc. Aero. \& Space Sci. (1965-11)

44) T. HAYASHI, On the Shear Instability of Structures caused by Compressive Load Proc. 16. Japan Nat. Congr. App. Mech. (1966), 149.

45) R. L. FOYE, "Compressive Strength of Unidirectional Composites", paper presented at AIAA
(1966-1).

46) 牧: 構造用複合材料研究会 (1968-3)

47) R. HuL, The Mathematical Theory of Plasticity (1950), Oxford Univ. Press, London.

48) S. W. Tsai, NASA Report CR-71 (1964).

49) S. W. Tșai, NASA Report CR-224 (1965).

50) S. W. TsaI \& V.D. AzzI, AIAA J., 4-2 (1966), 296

51) S. W. TsAI ほ加 2 名, NASA Report CR-620(1966)

52) O. Hofrman, J. Composite Materials, 1-2 (1967), 200.

53) 植村，山脇：第 3 回宇宙航空工学における FRP シン ポジゥム予稿集（1968-12-5）。 